\title{
LIBERTAD DE CONCIENCIA Y CONVIVENCIA EN PAREJA
}

\section{Dionisio Lamazares Femández}

Director de la Cátedra Femando de los Ríos Laicidad y Libertades Públic as (Carlos III)

\begin{abstract}
Resumen
Uno de los mayores actos de realización personal es aquel por el que la persona "dispone» de sí misma, entregando a otro su propio poder de decisión, sin que ello suponga una "enajenación» y una desrealización como «libertad», porque encuentra en el otro miembro de la pareja una respuesta similar. Por tanto, puede afirmarse que el derecho a convivir en pareja es un derecho constitucionalmente protegido en cuanto contenido esencial de la dignidad de la persona misma y de su derecho al libre desarrollo de la personalidad (artículo 10.1 CE), aunque sean legítimas las diferencias de trato en la medida en que las uniones no sean realidades equivalentes.
\end{abstract}

- Palabras clave: Libertad de conciencia; Convivencia en pareja; Dignidad personal; Igualdad

\begin{abstract}
Individual right to live together it's an essential part of individual dignity and free development of personality. All kinds of relationships deserve to be treated equally, unless these relations don't be equivalents realities.
\end{abstract}

- Keywords: Freedom of conscience; Common life; Individual dignity; Equal rights

I. Introducción - II. Uniones de hecho - III. Transexualidad y matrimonio. Orientación sexual y transexualidad - IV. Matrimonio homosexual - V. Matrimonio civil y matrimonio religioso VI. Matrimonio civil y ritos matrimoniales étnicos

\section{INTRODUCCIÓN}

La libertad de conciencia implica el derecho a tener unas u otras creencias, unas u otras ideas, a silenciarlas o manifestarlas, tanto de palabra (libertad de expresión y libertad de enseñanza) como de obra, con conductas y actitudes, acomodando éstas a 
las propias creencias o convicciones (derecho a la privacidad y objeciones de conciencia), y previamente a todo ello, entraña el derecho a la formación de la propia conciencia en libertad y para la libertad (derecho a la educación y a la información).

Al servicio de la libertad de conciencia y de la conciencia de la libertad están la laicidad y la tolerancia como principios constitucionales complementarios, dada la primacía de la libertad de conciencia entre los derechos fundamentales 1).

La libertad de conciencia cumple también la función de proteger la corresponsabilidad y participación política de los ciudadanos, contribuyendo a la formación de la conciencia colectiva y de la opinión pública, incluso a través del disenso, con un sentido de la justicia que se traducirá en la protección de las minorías 2). Así, en ocasiones, la libertad de conciencia y su ejercicio a través del disenso sustituye a la falta de cauces de participación democrática en la formación del concepto público de lo «justo» (desobediencia civil).

Es más, la razón de ser y la finalidad a la que, en última instancia, sirven las normas jurídicas y el Derecho es garantizar a todos un espacio lo más anchuroso posible para su libre y pleno desarrollo como personas, es decir, como radical libertad. El Derecho está al servicio de la libertad de conciencia de todas las personas en condiciones de igualdad. Como diría KANT, la limitación de ese ámbito de libertad y, por tanto, de la libertad de conciencia y de las normas de conciencia sólo tiene un fundamento: el respeto a esa misma libertad de los demás.

Por eso, en los ordenamientos democráticos el bloque mayor es el integrado, no por las normas imperativas, que imponen obligaciones o establecen prohibiciones, sino por las meramente facultativas o permisivas que abren cauces para el ejercicio de los derechos en orden a la máxima realización personal posible. Sería un contrasentido lo contrario ya que, en el supuesto extremo, conduciría al paradójico resultado de la negación misma de la libertad individual, porque el Derecho lo regularía todo como obligatorio o como prohibido, sin dejar ninguna zona a la libre decisión de la persona singular.

Es preciso preguntarse incluso si no existirá una zona de decisiones personalísimas, sustraídas a toda posible regulación jurídica no expresamente querida, bien por entrañar esa regulación una auténtica contradicción en sí misma (regulación jurídica del amor), bien porque la conciencia del sujeto percibe esas decisiones como esencialmente libres y, consecuentemente, su regulación jurídica es percibida como una agresión a su libertad y a su desarrollo en libertad como persona radicalmente libre, aunque la norma jurídica pueda coincidir con la de la propia conciencia.

La colisión entre norma de conciencia y norma jurídica se puede producir, según esto, por dos causas y adoptar dos formas diferentes:

1) Porque el ordenamiento jurídico tipifica como obligatorio lo que la conciencia considera prohibido o a la inversa, la norma jurídica tipifica como prohibido lo obligatorio en conciencia; se da, pues, una auténtica contradicción entre norma de 
conciencia y norma jurídica. Ese es el único supuesto de auténtica objeción de conciencia.

2) Porque el ordenamiento jurídico de la comunidad impone innecesariamente obligaciones o prohibiciones de conductas que la conciencia considera personalísimas, de exclusiva competencia de cada persona, y sus consecuencias, en principio, no afectan negativamente a la libertad de los demás; lo que la propia conciencia considera libre el ordenamiento jurídico lo considera prohibido u obligatorio; se da discordancia, no contradicción, entre lo libre en conciencia y un imperativo jurídico.

Obligación del legislador es evitar y sortear esos supuestos de contradicción o discordancia entre norma jurídica y norma de conciencia al formular sus leyes, ofreciendo en caso contrario, fórmulas que las superen. No basta con eliminar las posibles contradicciones entre norma jurídica y norma de conciencia; es necesario cerrar el paso a toda posible invasión ilegítima del Derecho en la zona de la libertad íntima de la persona.

Pues bien, uno de los supuestos en los que, en el marco de la moral pública, han de abrirse caminos despejados de prohibiciones y mandatos para que la persona decida con plena libertad es justamente el de la vida o no en pareja.

Punto obligado de partida lo es el artículo 10.1 que, al decir del TC, es «fundamento lógico y ontológico» de todos los derechos fundamentales ${ }^{1}$.

La persona se define como radical libertad ${ }^{2}$. Ahí está su grandeza y el fundamento de su dignidad: la libertad y la conciencia, o si se prefiere, la conciencia de su libertad. La persona es «digna» y merecedora de respeto en la medida en que actúa con total libertad y de acuerdo con sus propias creencias. En la medida en que es libre y se sabe libre. Eso es lo que la convierte en responsable de sus decisiones: libertad conciencia y coherencia son las bases de esa dignidad.

Dos son las vías para la suprema realización de la persona. La una es un continuum constituido por la cadena de decisiones en libertad adoptadas a lo largo de la vida. La otra es una decisión puntual: la decisión formal de aceptación de la propia finitud, en el acto supremo de la propia muerte.

De la cadena de decisiones que enhebran cada vida individual y que conforman el desarrollo de la personalidad y, en definitiva, la propia identidad, hay algunas especialmente decisivas desde el punto de vista de la realización de la persona como tal: la de vivir en pareja es, sin duda, una de ellas, dada la esencial constitución dialogal de la persona. Es ésta una afirmación en la que coinciden fenomenólogos y sociólogos al describir la relación amorosa.

\footnotetext{
${ }^{1}$ STC 53/1985, de 11 de abril, FJ 3.

2 LLAMAZARES FERNÁNDEZ, D., Derecho eclesiástico del Estado..., cit., pp. 259 y ss.
} 
La persona humana es un ser-con-los otros y este ser-con-los-otros forma parte integrante de su identidad. La persona es un ser esencialmente dialogal. El libre desarrollo al que se refiere el art. 10.1 no se refiere únicamente a la realización de sus potencialidades como ser singular aislado, sino a las que tiene también como tal ser dialogal.

El marco de la vida en pareja es uno de los más privilegiados, no el único, claro está, para este desarrollo armónico e integral. En esa atmósfera es posible el desarrollo en plenitud de esas dos facetas que responden a las dos actitudes posibles de la persona hacia el otro miembro de la pareja. Sólo en ese ámbito es pensable la plenitud de entrega y aceptación mutuas, la generosa puesta de cada uno a disposición del otro, sin apropiación indebida y sin enajenación.

En efecto, como ha puesto de relieve VON HILDEBRAND ${ }^{3}$, en esa relación se dan dos movimientos esenciales que implican, en todo caso, una salida de uno mismo al encuentro con «el otro» o, al menos, con «lo otro»: lo que Santo Tomás denominó la intentio unitiva y la intentio benevolentiae. El primero está provocado por la atracción, en ocasiones fascinación, de «lo otro» o «del otro», que es percibido como algo que puede proporcionar «goce y disfrute» y la salida de uno mismo no tiene, en principio, otro objetivo que poseerlo, disfrutarlo y gozarlo; la intentio unitiva es así, en principio, egoísta. La intentio benevolentiae, en cambio, es justamente lo contrario: la salida es provocada por la fascinación o atracción de «lo otro», no como algo «disfrutable y gozable», sino como algo o alguien que merece toda la entrega de quien se siente fascinado y atraído: la intentio benevolentiae es generosa; la intentio unitiva persigue el bien propio, es posesiva; la intentio benevolentiae es donación y entrega, persigue el bien ajeno.

Los movimientos recíprocos de entrega y aceptación solo son concebibles en su máxima realización en el seno de la pareja. Ni la entrega ni la aceptación pueden repartirse sin que merme su intensidad.

Sólo cuando se combinan ambos movimientos y tendencias en los dos miembros de la pareja que se encuentran, sólo cuando son mutuos y recíprocos y si se dan simultáneamente en cada uno de los sujetos, se eliminan los riesgos de que la entrega y donación supongan enajenación, y se consigue que la posesión egoísta se transforme en apertura generosa a la aceptación de la entrega del otro. Sólo en este marco es pensable que entrega-aceptación sean totales, incondicionales y sin reservas; sólo entonces la entrega y la aceptación son excluyentes de cualquier otra a ese nivel de profundidad interpersonal; ni la entrega ni la aceptación, así entendidas, son comparables, porque lo que cada uno entrega al otro y lo que acepta del otro es su «mismidad»; lo que cada uno pone a disposición del otro y acepta de ese otro es parte de la capacidad misma de decidir en libertad, es parte de su propia libertad: no son «sus cosas», es parte de su «sí mismo» lo que entrega y acepta del otro. Como es evidente, esto sólo es pensable y posible en la relación de pareja. La relación multilateral excluiría esa profundidad de entrega y aceptación.

${ }^{3}$ Metaphysik der Gemeinschaft, Regensburg, 1955, pp. 117-118 y 121-128. 
Pues bien, no parece osado afirmar que, teóricamente al menos, ése es el marco más adecuado para la realización de la persona como tal. Me atrevería a afirmar más: sólo en ese marco es posible esa realización. Ese esquema dialogal se repite en los esquemas ascéticos y místicos en su pretensión de desarrollo personal hacia la perfección de quienes han renunciado a una vida en pareja por sublimación.

En efecto, el supremo acto de realización personal, si exceptuamos el de la aceptación de la propia muerte, es aquel por el que la persona «dispone» de sí misma y de su propia capacidad de decisión, entregando a otro su propio poder de decisión, sin que ello suponga una «enajenación» y una desrealización como «libertad», porque encuentra en el otro miembro de la pareja una respuesta similar. El «yo» y el «tú» han formado un «nosotros» que es el nuevo centro ideal de imputación de muchas de las decisiones futuras ${ }^{4}$.

Otra cosa es que los seres humanos estemos en condiciones de alcanzar tal ideal; más aun, de que nos sintamos con fuerzas para intentarlo, si somos realistas. De ahí la necesidad de que el Derecho deje abierta la posibilidad del modelo de convivencia en pareja que mejor se acomode a la percepción que tengan de su propia identidad sus miembros.

La convivencia en pareja es un instrumento valiosísimo desde el punto de vista tanto de la integración de la conciencia, de su formación y madurez, como de la identidad personal y, en definitiva, del libre desarrollo de la personalidad.

Como consecuencia de todo lo anterior, en conexión con el art. 16.1 que es su verdadero fundamento, puede afirmarse que el derecho a convivir en pareja es un derecho constitucionalmente protegido en cuanto contenido esencial de la dignidad de la persona misma y de su derecho al libre desarrollo de la personalidad (artículo $10.1 \mathrm{CE}$ ), aunque sean legítimas las diferencias de trato con respecto a una determinada forma de unión, como es el matrimonio, ya que no son realidades equivalentes.

Es verdad que desde un punto de vista formal no se puede decir que estemos ante un derecho fundamental, a pesar de que el TS utilice alguna vez esta terminología 5 , a diferencia de lo que ocurre en los arts. 1 y 2 de la LFB en el que se configura un derecho protegido por el recurso de amparo ${ }^{6}$, pero no lo es menos que ese derecho es parte esencial integrante de la dignidad personal y del derecho al libre desarrollo de la propia identidad, aunque no goce de la protección directa del recurso de amparo. En todo caso es un principio constitucional que vincula a todos los poderes públicos (art. 9.3 CE) y que deberá ser tenido en cuenta en el desarrollo normativo y en la

${ }^{4}$ Ésta es una de las ideas centrales de MÜHLEN, H., Una mystica persona, 2te Aufl., München, 1968; y Der heilige Geist als person der Trinita $t$ bei der Inkarnation und Gnadenbund: Ich, Du, Wir, 2te Aufl., Münster, 1967.

5 STS de 15 de julio de 1988, FJ 10, párr. 2.

${ }^{6}$ DE VERDA Y BEAMONTE, J. R., «Principio del libre desarrollo de la personalidad y ius connubii», en Uniones de hecho (MARTINELL Y ARECES PIÑOL edts.), Universidad de Lleida, 1998, p. 479. 
aplicación de los derechos y libertades del Título primero, no sólo explícitos (derecho al matrimonio), sino también de los implícitos por necesidad lógica (el derecho a vivir en pareja), ya que a ambos es aplicable el razonamiento del $\mathrm{TC}^{7}$ al considerar que esas decisiones se vinculan con las convicciones y creencias más íntimas de la persona y son, por tanto, realización y consecuencia inseparable del derecho fundamental consagrado en el art. 16 CE en relación con el art. 10.1, ambos de la CE.

Lo que sí es un derecho fundamental es el derecho a optar por una u otra forma de convivencia en pareja como marco para la mejor realización del libre y pleno desarrollo de la personalidad, así como la elección de tipo de compromiso de pareja, de acuerdo con la percepción de la capacidad de entrega-aceptación que tenga cada cual.

Lo que parece meridianamente claro es que, de acuerdo con nuestra Constitución lo primero es el derecho a vivir o no en pareja y sólo en segundo lugar, como una forma especialmente protegida, el de poder elegir hacerlo en matrimonio o no y, sólo en tercer lugar, el de poder elegir entre matrimonio religioso o civil, de manera que el llamado ius nubendi no incluye sólo dos contenidos, positivo uno (contraer matrimonio) y negativo otro (no contraerlo) ${ }^{8}$, sino a vivir en pareja distinta del matrimonio.

Ahora bien, que sea un derecho no quiere decir que sea un deber: la persona es radicalmente libre para optar vivir en pareja o no, o para elegir entre distintas formas de convivencia en pareja. La pregunta es si el Estado puede obligar a que esa vida en pareja adopte una forma determinada o no. De otra manera dicho, si esa decisión se encuadra en el círculo de los derechos personalísimos sustraídos a la invasión del derecho o no.

Nuestra Constitución ni ordena que los españoles vivan en pareja ni se lo prohíbe; no les obliga a adoptar un modelo determinado de convivencia (matrimonio), ni le prohíbe ése u otros modelos posibles. Todo lo cual, si lo conectamos con el art. 10. 1 CE conduce a una conclusión inequívoca: estamos ante una decisión radicalmente libre de la persona individual situada en la esfera de los derechos personalísimos sustraídos a la regulación del Derecho salvo para posibilitar y facilitar su realización. Esta libertad, como veremos más adelante, incluye la libertad para optar también entre una pareja heterosexual o una pareja homosexual. Todo depende de cuál sea la percepción que cada uno tiene de su identidad sexual que parte integrante de su identidad personal.

La Constitución se limita (art. 32) a formular como derecho constitucional la opción por uno de esos modelos, el matrimonio, seguramente por ser el más común y con mayor arraigo histórico y social, reservando a la ley su regulación básica de desarrollo, pero no excluye ningún otro, aunque en los demás casos no existe mandato constitucional expreso al legislador ordinario para que legisle y desarrolle legislativamente ese derecho.

${ }^{7}$ STC 47/1993, FJ 3, párr. 2.

${ }^{8}$ DE VERDA y BEAMONTE, J. R., en Uniones de hecho, cit., p. 483. 
Ahora bien, la falta de este mandato constitucional expreso no quiere decir que no haya que considerarlo implícito en la medida en que ese desarrollo legislativo sea necesario para garantizar que la igualdad y la libertad sean reales y efectivas (art. 9.2 CE).

Justamente ése es el principio que marca también los límites de los poderes públicos y del ordenamiento al regular las posibles alternativas y al atribuir o negar unos u otros efectos jurídicos a las opciones individuales. No se trata sólo de alternativas permitidas y no penalizadas, sino de alternativas que responden a un derecho de libertad que los poderes públicos han de respetar, proteger y promocionar en condiciones de igualdad, excluida cualquier discriminación negativa con fundamento en la opción concreta elegida. Otra cosa implicaría una violación del derecho de libertad de conciencia y, en última instancia, un atentado a la dignidad de la persona y a su libre desarrollo (art. 16.1 en relación con el 10.1 CE) ${ }^{9}$.

La primera opción implica la elección entre convivir o no en pareja. La segunda entre pareja heterosexual $\mathrm{u}$ homosexual. La tercera entre matrimonio y no matrimonio. La cuarta implica la opción entre distintos tipos de matrimonio, civil o religioso; con la posibilidad en este último caso (es un derecho para ambos fueros con prevalencia del primero sobre el segundo, caso de contradicción) de ensayar el modelo ideal de la indisolubilidad, tanto si es religioso como si es civil, pero cuyos deberes no pueden imponerse por el derecho secular sin invadir el terreno vedado de la conciencia. El derecho secular puede y debe abrir esas posibles vías, pero no puede garantiza, con su imperatividad, el cumplimiento de los respectivos compromisos interpersonales, sin invadir ilegítimamente el núcleo de la intimidad.

El modelo más generalizado y habitual es el de la pareja heterosexual, y es que factores de los dos movimientos señalados -intentio unitiva e intentio benevolentiaeson tanto la atracción sexual como la atracción erótica integradas en la relación de ágape y donde esto aparece con más nitidez en el marco cultural en que nos movemos es precisamente en las parejas heterosexuales.

Ahora bien, eso no excluye otras posibilidades. No excluye la convivencia more uxorio entre homosexuales, desde el momento que el ordenamiento ha optado por desvincular matrimonio y procreación ${ }^{10}$; la modificación ${ }^{11}$ del art. 44 del CC ha abierto la posibilidad de matrimonios homosexuales. Lo que está claro es que la relación entre los miembros de la pareja puede incluir, en cualquiera de los tipos reseñados con sus propias modalidades, esos tres niveles del amor, de un lado y, de otro, no debemos olvidar que tanto el sexo como la orientación sexual forman parte integrante de la identidad personal y, por tanto, de la dignidad personal y del derecho al libre desarrollo de la personalidad.

A partir de aquí, dos son las preguntas a las que se debe dar respuesta: $1^{\mathrm{a}}$ ) en cumplimiento del mandato constitucional implícito, si el poder legislativo regula

9 En ese mismo sentido se ha manifestado el TC en la S. 184/1990, aun cuando el resto de la misma sobre las uniones de hecho sea difícilmente armonizable, por no decir contradictoria, con este fundamento de la libertad de elección.

10 PANTALEÓN PRIETO, F., «Ponencia» en Uniones de hecho..., cit., p. 70.

11 Ley 13/2005, de 1 de julio (BOE de 2 de julio). 
jurídicamente las uniones de hecho, ¿qué derechos debe reconocerles?; 2a ) ¿por qué modelo de matrimonio debe inclinarse si quiere respetar escrupulosamente los principios constitucionales y, en especial, el derecho de libertad de conciencia?

Tres son las premisas que hace ya unos años consideraba como indudables PANTALEÓN ${ }^{12}$, y que yo suscribía : $1^{\text {a }}$ ) constitucionalidad del trato diferenciado entre matrimonio y convivencia extramatrimonial con discriminación positiva de la primera ${ }^{13}$ que no implica discriminación negativa de la segunda; 2a) inconstitucionalidad de la consideración de la convivencia more uxorio, heterosexual u homosexual, como ilícita; y 3ª) esa convivencia extramatrimonial no puede ser tratada peor que la no convivencia en pareja, ya que, añadimos nosotros, ello implicaría su discriminación negativa, que la haría inconstitucional; $4^{\mathrm{a}}$ ) tampoco es inconstitucional tratar igual, equiparar el tratamiento de las uniones de hecho al matrimonio, lo único que sería inconstitucional sería tratarlas mejor ${ }^{14}$.

Hoy me parece que la Constitución, habida cuenta de otros textos internacionales como la carta de Derechos Fundamentales ${ }^{15}$, incluida en el Tratado de la Unión, me obliga a dar un paso más. Me parece más que dudoso seguir manteniendo la constitucionalidad del trato privilegiado o de discriminación positiva, del matrimonio frente a otras posibles formas de unión estable en pareja, porque, por más vueltas que le demos, tal discriminación se traducirá inevitablemente en discriminación de los miembros de la pareja, por razón de convicciones o de orientación sexual, de inconstitucionalidad evidente. Otra cosa es el trato diferenciado de unas y otras formas de convivencia en pareja, siempre que no entrañen ni privilegio ni discriminación en cuanto a los derechos y deberes de sus miembros.

\section{UNIONES DE HECHO}

Entendemos aquí por uniones, parejas o matrimonios de hecho, o uniones more uxorio, la convivencia en pareja, de carácter estable, de dos personas, del mismo o distinto sexo, sobre la base de una afectividad, incluida la sexual, similar a la del matrimonio. La regulación jurídica de este tipo de parejas se inicia en los países del Norte de Europa acogiendo a aquellos supuestos en los que la pareja no puede contraer matrimonio, especialmente en el caso de parejas homosexuales; pero luego se abriría también esta posibilidad a quienes no tienen impedimento alguno para contraer matrimonio, pero que voluntariamente renuncian a esa formalización de su convivencia ${ }^{16}$.

12 «Ponencia» en Uniones de hecho..., cit., pp. 73-74.

13 En ese sentido STC 66/1994.

14 PANTALEÓN PRIETO, F., «Ponencia», en Uniones de hecho..., cit., p. 74.

15 Su art. 9 , al consagrar el derecho no al matrimonio sino a fundar una familia, silencia la referencia diferenciada a hombre y mujer, dejando abierta a la titularidad de ese derecho por una pareja homosexual.

16 ALONSO PÉREZ, I., El reconocimiento de las uniones no matrimoniales en la Unión europea. Análisis y sinopsis de las leyes autonómicas en vigor, Bosch, Barcelona, 2007, pp. 41 y ss. 
La pareja de hecho puede ser consecuencia de una decisión voluntaria de los miembros de la pareja o no.

Esto segundo es lo que ocurre cuando se trata de personas que, de acuerdo con el derecho vigente no pueden contraer matrimonio, bien por falta de capacidad o bien por estar afectados por un impedimento indispensable (persistencia de un vínculo matrimonial anterior o Ser ambos miembros de la pareja del mismo sexo).

Pero puede ser también consecuencia de una decisión voluntaria. En este caso estamos ante el ejercicio del derecho de libertad de conciencia. Si se excluye el matrimonio es porque en el fondo, más o menos oscuramente, no se quiere que las relaciones interpersonales entre los miembros de la pareja estén sometidas al moldeamiento de la norma jurídica. Se sospecha que actitud de amor y actitud obligada por el Derecho son de imposible armonización y se presiente que el Derecho es la muerte del amor. No es un capricho nacido de la frivolidad. Es una decisión legítima en ejercicio del derecho fundamental de libertad de conciencia que todos deben respetar y los poderes públicos defender.

Eso es lo único que, en principio hay que presumir que excluyen los miembros de la pareja, salvo que manifiesten otra cosa: la juridificación de las relaciones interpersonales. Nada más. Lo frívolo es llevar más allá la presunción, como ha hecho el Tribunal Supremo. Me parece una presunción no suficientemente fundada. Lo más probable, base de la presunción, es lo contrario.

La opción por la convivencia more uxorio en una pareja de hecho no implica que se excluya cualquier tipo de protección jurídica, ni de la pareja en cuanto tal, ni de los miembros de la pareja en su condición de tales. Lo único que con seguridad se excluye de la regulación jurídica son las relaciones interpersonales entre los miembros de la pareja. No existe base para interpretar la voluntad de la pareja más allá, salvo que expresamente lo manifiesten No se excluyen de tal regulación ni las relaciones con los hijos, ni las relaciones con el Estado o con terceros particulares.

No falta quien entiende que la dotación de un estatuto jurídico propio a las uniones de hecho estaría en contradicción con la voluntad de los miembros de la pareja ${ }^{17} \mathrm{y}$ que su regulación por vía legislativa sería inconstitucional ${ }^{18}$, pero no es ésa la posición doctrinal dominante ${ }^{19}$, ni parece haberlo entendido así el propio poder

17 GITRAMA GONZÁLEZ, M., «Nota sobre la problemática jurídica de las personas no casadas», en Homenaje a Beltrán de Heredia, Madrid, 1984.

18 FOSAR BENLLOCH, «La Constitución española de 1978 y la unión libre», en RJC, núm. 4, 1982, p. 925; CANTERO NÚÑEZ, F., «Reflexiones en torno a la pretendida regulación de las uniones de hecho», en Revista de Derecho Privado, marzo, 1995, pp. 219-224. Un resumen de las razones en pro de su no regulación por el Derecho en MARTÍNEZ TAPIA, R., «Las parejas de hecho ante el pensamiento jurídico: Reflexiones en torno a algunos problemas teóricos», en AAVV, Parejas de hecho. Curso de verano de la Universidad Complutense en Almería, Granada, 1996, pp. 238-240. Sobre las razones en contra, ibídem, pp. 240 y ss.

19 Cfr. CLAVERÍA GONZÁLEZ, H., «Hacia una nueva concepción del matrimonio», en La Ley, 1, 1983, pp. 1289 y ss., ya se manifestaba en este sentido. 
legislativo que ha tenido pendientes de discusión parlamentaria varias proposiciones de ley con este contenido ${ }^{20}$, siguiendo la orientación de las instituciones europeas, en especial de su Parlamento, incluso respecto a la aplicación de esas normas también a las parejas homosexuales.

Es especialmente vigorosa la argumentación de PANTALEÓN para quien esa hipotética legislación «sería una intolerable intromisión en la autonomía de la voluntad y en el libre desarrollo de la personalidad» que «estaría impidiendo la libre opción, que entra en el campo del libre desarrollo de la personalidad, de la dignidad de la persona humana, de organizar la convivencia en pareja al margen del ordenamiento en aquello que sólo afecta a la decisión de las personas adultas que deciden convivir; decisión que debe ser exquisitamente respetada por el legislador» ${ }^{21}$.

El argumento es irreprochable por lógico, pero susceptible de matización. También la seguridad jurídica es un valor constitucional (art. 9.3 CE) y es obligación de los poderes públicos velar por que la libertad y la igualdad sean reales y efectivas (art. 9.2 CE). Podría ser inconstitucional imponer un determinado modelo de convivencia more uxorio, pero no el ofertar un modelo posible, en todo caso de libre elección, con posibilidad de las modificaciones que la pareja estimara conveniente, y que funcionara como subsidiario para el caso de inexistencia de modelo convenido, siempre que fuera necesario para salvaguardar derechos de alguno de los convivientes, de los hijos o de terceros.

El art. 39 consagra la obligación de los poderes públicos de asegurar la protección social, económica y jurídica de la familia. Es obvio que la protección jurídica incluye la regulación jurídica, de un lado. De otro, según el TC, en este concepto de familia hay que considerar incluidas a las parejas de hecho.

No existe mandato constitucional explícito. Es verdad. Pero se deduce ese mandato de la obligación que el legislador impone a los poderes públicos, también al legislativo, de proteger jurídicamente a la familia.

Hasta el momento el parlamento del Estado ha sido incapaz de aprobar una ley sobre las uniones de hecho. Se han presentado en varias legislaturas varias proposiciones de ley que no han llegado nunca al pleno del Congreso.

Están ya en vigor, en cambio, varias leyes aprobadas por los parlamentos autónomos, muy diferentes dadas las diferencias del ámbito de competencias de las diversas comunidades autónomas. Puede decirse que hay algo en lo que coinciden: la tendencia a la equiparación por analogía con el matrimonio ${ }^{22}$.

Y esa es también la orientación mayoritaria, no sin dudas y vacilaciones, del Tribunal Supremo y del Tribunal Constitucional.

\footnotetext{
20 Han presentado proposiciones de ley con este contenido IU, PSOE, UC y el propio PP.

21 PANTALEÓN PRIETO, F., «Ponencia», en Uniones de hecho..., cit., p. 74.

22 Sobre las leyes autonómicas, con sinopsis de las mismas, ALONSO PÉREZ, I., El reconocimiento de las Uniones no matrimoniales, cit., pp. 79 y ss.
} 


\section{TRANSEXUALIDAD Y MATRIMONIO. ORIENTACIÓN SEXUAL Y TRANSEXUALIDAD}

La sexualidad y la orientación sexual forman parte integrante de las señas de identidad de la persona ${ }^{23}$. Pertenecen a sus vivencias más íntimas, por lo que parecen terreno ajeno al Derecho, que deberá limitarse a proteger la libertad correspondiente, siempre que no choque con los derechos y libertades de los demás, ni con ningún otro elemento del orden público. «El derecho a la identidad sexual como expresión del más amplio derecho a la identidad personal, debe, pues, engrosar la lista de derechos de la personalidad, en estrecha conexión con otros derechos de la misma naturaleza, como son el derecho al libre desarrollo de la personalidad, la dignidad humana, la tutela de la salud, el respeto a su intimidad y a la protección de su integridad física y moral» ${ }^{24}$.

En esa línea, el art. 14 CE excluye todo tipo de discriminación por razón de sexo, y el CP protege la condición sexual y la orientación sexual contra cualquier tipo de discriminación, tipificando como delito la provocación a la discriminación, al odio o la violencia contra grupos o asociaciones por razón de su sexo u orientación sexual (art. 510.1), así como la difusión de informaciones injuriosas sobre ellas (art. 510.2), y la denegación de un derecho a alguien por esa misma razón, tanto si quien lo deniega es un particular encargado de un servicio público, como un funcionario, con agravación de la pena en este último caso, tanto si la denegación se hace a algún individuo como si se hace a una fundación, asociación, sociedad o corporación o sus miembros en razón de su pertenencia a ellas (art. 511). Incluso se tipifica como delictiva ese tipo de conducta cuando en el ejercicio de sus actividades profesionales o empresariales denegaren a alguien una prestación por las mismas razones (art. 512).

Especial atención merecen los supuestos de transexualidad.

En sentido propio se habla de transexualidad cuando concurren simultáneamente estas dos circunstancias:

$\left.1^{a}\right)$ Se trata de personas en las que se da una total disociación entre su apariencia sexual externa (órganos sexuales) y su vivencia interna y la percepción de la propia identidad como del sexo contrario: total discordancia, contradicción incluso, entre ambos.

$2^{a}$ ) La vivencia personal de esa discordancia es tan fuerte e intensa que no sólo no se acepta la propia apariencia sexual externa, sino que se siente en forma irresistible como algo intolerable, hasta el punto de que esa vivencia se traduce en ocasiones

23 LÓPEZ-GALIACHO, J., La problemática jurídica de la transexualidad, Madrid, 1998, pp. 97-194; LARICCIA, S., Coscienza e liberta '..., cit., 306; BARILE, P., Diritti dell'uomo e liberta` fondamentali, Il Mulino, Bologna, 1984, p. 27.

24 LÓPEZ-GALIACHO, J., La problemática jurídica..., cit., p. 111. 
en un impulso no menos irresistible hacia la automutilación para eliminar esa apariencia, llegándose incluso al suicidio ${ }^{25}$.

Tres son las preguntas que hay que plantearse respecto al sometimiento de estas personas a las operaciones quirúrgicas destinadas a hacer desaparecer la apariencia externa sexual, armonizándola con la percepción interna de su identidad sexual: $1^{\text {a }}$ ) si es penalmente punible tanto el sometimiento a esas operaciones como la realización de las mismas por personal médico; $2^{\mathrm{a}}$ ) si realizada esa operación es legalmente posible la inscripción en el Registro civil; $3^{\text {a }}$ ) cuál es su situación jurídica posterior respecto de la posibilidad de contraer matrimonio.

En cuanto a la primera cuestión, el art. 156 CP, que reproduce el art. 428 del anterior $\mathrm{CP}$, considera exceptuado del tipo del delito de lesiones y de toda responsabilidad penal la cirugía transexual cuando ha mediado «consentimiento válido, libre, consciente y expresamente emitido» por el sujeto paciente, «salvo que el consentimiento se haya obtenido viciadamente, o mediante precio o recompensa, o el otorgante sea menor de edad o incapaz, en cuyo caso no será válido el prestado por éstos ni por sus representantes legales».

«En el conflicto de identidad sexual (de sus impulsos, de sus emociones) que vive la persona que desea cambiar de sexo debe prevalecer el sentimiento que la misma tiene de pertenecer a otro distinto del atribuido por sus genitales. La persona ejercita la libre decisión de estar en el sexo que quiere y el Derecho debe proteger esta elección atribuyéndole efectos jurídicos» ${ }^{26}$.

Por su parte, el TS ha dado reiteradamente respuesta a las otras dos preguntas: afirmativa a la segunda y negativa a la tercera, siguiendo criterios acordes con la jurisprudencia del $\mathrm{TEDH}^{27}$.

La cuestión que aquí hay que plantearse es si quienes padecen tal situación tienen derecho a cambiar esa apariencia externa y con qué consecuencias jurídicas, tanto respecto a sí mismos como respecto de terceros.

Mediante una operación quirúrgica es posible cambiar esa apariencia externa; naturalmente esa operación puede ser tipificada como una mutilación susceptible teóricamente de penalización para quien la realiza por aplicación de la regla general del artículo $418 \mathrm{CP}$.

La reforma del CP de 1983 despenalizó los supuestos de «cirugía transexual realizada por facultativos cuando mediase consentimiento del lesionado» (artículo 428 CP).

25 La STS de 19 de abril de 1991 habla de «irresistible sentimiento de pertenencia al sexo contrario, rechazo del propio y deseo obsesivo de cambiar la morfología genital», FJ 3.A; cfr. también STS de 15 de julio de 1988, FJ 7.

26 LÓPEZ-GALIACHO, J., La problemática jurídica..., cit., p. 115.

27 LÓPEZ-GALIACHO, J., ibidem, pp. 126-141 y 334-339. 
Alineándose con la orientación progresista de los ordenamientos jurídicos de los países de nuestro entorno europeo, el Tribunal Supremo, dio un importante paso adelante al reconocer a los transexuales el derecho a cambiar de sexo y a que ese cambio figurara en el Registro Civil. Ahondando en la línea anteriormente abierta por él mismo según la cual en el cambio de sexo se da una auténtica ficción jurídica $^{28}$, a la que añade más adelante con base en el art. 10.1 CE que el cambio de sexo es expresión del derecho al libre desarrollo de la personalidad ${ }^{29}$, considera obligatoria para el oficial del registro la inscripción del cambio de sexo que, a diferencia de lo que acontece en el caso de los hermafroditas en que la inscripción es consecuencia de la eliminación de la ambigüedad e indefinición sexual, no tiene efectos retroactivos (ex tunc), sino sólo a partir de ese momento (ex nunc); no es declarativa, sino constitutiva ${ }^{30}$.

Desde el punto de vista procedimental, la DGRN para la inscripción registral exigía tanto que se hubiera practicado la operación quirúrgica de cambio de sexo aparente, como que se hubiera pronunciado sentencia, que se configuraban así como requisitos previos $^{31}$ a esa inscripción que, en todo caso, debe ser irreversible ${ }^{32}$.

La Ley vigente ${ }^{33}$ ha venido a modificar estas exigencias. No es necesaria ni la sentencia y la operación quirúrgica. Los requisitos exigibles son otros: informe de médico o psicólogo clínico que diagnostique la disonancia entere sexo morfológico y sexo psicosocial, así como ausencia de trastornos de personalidad que pudieran influir en la existencia de la disonancia (art. 4).

Lo más destacable de las sentencias de nuestro Tribunal Supremo ${ }^{34}$ es la argumentación que teje para justificar su decisión; y es que toma como base y punto de partida el artículo 10.1 CE, intentando encontrar en él una respuesta adecuada a un problema nuevo por su forma de manifestación, por su dimensión social y por el nuevo cariz derivado de las posibilidades de las modernas técnicas quirúrgicas. Evidentemente se esconde ahí una no confesada configuración del derecho de los transexuales a cambiar de sexo como un derecho fundamental. El problema es el de hasta dónde se extiende el contenido de ese derecho. ¿Todo se queda en el derecho a poder exigir la inscripción y a poder utilizar un nuevo nombre? El Tribunal Supremo niega que pueda tener otros efectos, como el de atribuir al transexual el derecho a contraer matrimonio ${ }^{35}$.

28 STS de 2 de julio de 1987, FJ 3.1.

29 STS de 15 de julio de 1988, FFJJ 10 y 13; STS de 3 de marzo de 1989, FJ 3.

30 STS de 19 de abril de 1991, FJ 3; cfr. LÓPEZ-GALIACHO, J., La problemática..., cit., pp. 282 y ss.

31 Resolución de 11 de mayo de 1995, FJ 2.

32 LÓPEZ-GALIACHO, J., La problemática..., cit., pp. 285-287.

33 Ley 3/2007, de 15 de marzo, reguladora de la rectificación registral de la mención relativa al sexo de las personas (BOE 16 de marzo).

34 SSTS de 2 de julio de 1987, FJ 10, párr. 2 letra d) y FJ 13, letra d) y de 3 de marzo de 1989, FJ 3 in initio.

35 Sobre el derecho del transexual a contraer matrimonio vid. LLAMAZARES CALZADILLA, M. C. y PARDO PRIETO, P., «Transexualidad y derecho a contraer matrimonio en España hoy: ¿una luz al final del túnel?», Derecho de familia y libertad de 
Pudiera parecer razonable afirmar que el derecho a cambiar de sexo una vez ejercitado no habilita para el matrimonio, como parecía pensar el TS en la referida sentencia de 1987 y en sentencias posteriores así lo manifiesta expresamente ${ }^{36}$. Una cosa es que la operación quirúrgica haya eliminado una determinada apariencia sexual y otra bien distinta que esa persona haya dejado de pertenecer a ese sexo, cualesquiera que sean sus vivencias íntimas. De ser esto cierto, el artículo 32 de la Constitución Española es terminante: el matrimonio se configura como una unión heterosexual. Otra cosa bien distinta sería que, por analogía, en función de la realización integral de la persona, se puedan equiparar las uniones de hecho en que una de las partes es un transexual a otras uniones heterosexuales desde el punto de vista de su tratamiento jurídico.

Antes de someterse a la operación quirúrgica de cambio de sexo podían contraer matrimonio con las que tenían un sexo distinto al suyo aparente, puesto que la impotencia no es considerada como impedimento civil. ¿Pierden este derecho en virtud de la operación quirúrgica, que según el TS no cambia su verdadero sexo, o lo conservan?

De ser afirmativa la respuesta nos encontraríamos con que tienen derecho al matrimonio con personas, desde el punto de vista de su apariencia sexual externa y desde el punto de vista de su identidad registral, del mismo sexo. No genera menor perplejidad la respuesta negativa ¿por qué pierden ese derecho si no ha habido un cambio real de sexo?

De iure condendo la única respuesta jurídicamente congruente era que se les reconociera el derecho a contraer matrimonio con personas con sexo distinto del nuevo suyo registral. Una vez «rectificado su sexo registral», debe gozar «de todos los derechos inherentes a su nueva condición» ${ }^{37}$, tanto en el Derecho de familia como en el sucesorio, etc. ${ }^{38}$. Es más, así debería establecerse por ley, no dejando la solución de los casos concretos en manos de los jueces ${ }^{39}$ y así se ha hecho en la Ley sobre modificación de la referencia al sexo en el registro.

La DGRN se había decantado abiertamente por esa la solución reconociendo a los transexuales operados el derecho a contraer matrimonio porque, aunque el legislador español no ha resuelto este problema, en las sentencias del TS sus consideraciones sobre la hipotética nulidad del matrimonio contraído por los homosexuales por falta de consentimiento matrimonial, no son «la ratio decidendi» de las mismas y, por tanto, no crean jurisprudencia ${ }^{40}$.

conciencia en los países de la Unión Europea y el Derecho comparado, Universidad del País Vasco, San Sebastián, 2001, pp. 563-583.

36 STS de 15 de julio de 1988, FFJ 10, párr. 2 y 13, párr. 13, d); STS de 3 de marzo de 1989, FJ 2; STS de 2 de octubre de 1991.

37 LÓPEZ-GALIACHO, J., La problemática jurídica..., cit., p. 368.

38 LÓPEZ-GALIACHO, J., ibidem, pp. 297 y ss.

39 LÓPEZ-GALIACHO, J., ibidem, pp. 364 y ss.

$40 \quad$ Res. de 8 de enero de 2001, FJ 4. 
La negativa del TS a reconocer el derecho al matrimonio a los transexuales que han inscrito en el Registro su cambio de sexo sobre la base de que no ha habido un cambio del sexo biológico sino sólo del morfológico, es más que cuestionable. En efecto, parece perfectamente razonable «afirmar a priori que la noción legal de sexo se determina exclusivamente por criterios morfológicos sin entrar en mayores análisis biológicos o de cromosomas», si tenemos en cuenta que la inscripción original, practicada con ocasión del nacimiento, en la que se determina el sexo (art. 41 LRC) se hace sobre la base de la declaración de quien tenga conocimiento cierto del hecho (art. 42 LRC y art. 328 CC) que no puede contar más que con una apreciación morfológica, sobre la base de los conocimientos comunes que permiten diferenciar a los sexos ${ }^{41}$.

En dos recientes sentencias el Tribunal Europeo de Derechos humanos ${ }^{42}$, en un giro de ciento ochenta grados con respecto a decisiones anteriores, por unanimidad ha reconocido la equiparación plena de los transexuales con quienes tienen el sexo que ellos han adquirido mediante la operación quirúrgica y que esa equiparación incluye su derecho a celebrar matrimonio con personas de distinto sexo legal.

El Tribunal es consciente de su cambio y lo justifica en atención a los cambios médicos, sociológicos y de Derecho comparado por la orientación convergente de los ordenamientos de Europa en el reconocimiento de esta igualdad de derechos a los heterosexuales. Apoya fundamentalmente su decisión en el art. 8 de la Convención: en el derecho al libre desarrollo de la propia personalidad y en el derecho a la integridad física y moral y a la elección de la identidad sexual ${ }^{43}$.

Como hemos dicho, la nueva ley no exige para la inscripción ni la previa operación quirúrgica de cambio de sexo morfológico ni una sentencia firme que lo avale. De otra parte, al hacer posible los matrimonios entre personas del mismo sexo desaparece cualquier obstáculo para el matrimonio de transexuales con personas de idéntico sexo morfológico pero diferente sexo psicosocial y registral.

\section{MATRIMONIO HOMOSEXUAL}

La Ley 13/2005 modifica el art. 44 del CC dejando la puerta abierta a los matrimonios entre personas homosexuales, sumándose así España a los países cuyos ordenamientos admitían ya esta posibilidad: Bélgica, Holanda, Canadá, España, Sudáfrica y el Estado de Massachusetts en EE.UU.; a los que recientemente se ha unido Portugal.

41 TOLDRÁ I ROCA, M. D., «La unión de las personas transexualizadas: límite jurisprudencial al ius nubendi», en Uniones de hecho. XI Jornades juridiques, edts. Martinell-Areces, Lleida, 1998, p. 451.

42 I. C Reino Unido, de 11 de julio de 2002 (Hudoc, REF 00003797), y Christine Goodwin c. Reino Unido, de 11 de julio de 2002 (Hudoc Ref 00003798).

43 En ambas sentencias ver FJ I. 
La discusión no siempre serena se centró y sigue planteada en torno a la constitucionalidad de la reforma. De hecho sus detractores tienen planteado un recurso de inconstitucionalidad ante el TC.

Dos son los puntos de apoyo del recurso: la interpretación correcta del art. 32 deja completamente cerrada tal posibilidad y la admisión del matrimonio homosexual entraña la desnaturalización de matrimonio como garantía institucional.

\section{Criterios de interpretación del art. 32.1 CE}

Si algo es evidente, es que las expresiones literales del art. 32.1 no son todo lo claras y terminantes que hubiera sido de desear. Lo que dice es que «el hombre y la mujer tiene derecho a contraer matrimonio con plena igualdad jurídica», expresión en la que están claras dos cosas: que el hombre y la mujer tienen derecho a contraer matrimonio y que tienen derecho a contraerlo con plena igualdad jurídica. Lo que no se añade es «entre sí», porque la plena igualdad jurídica no es aplicable únicamente al caso de que sea matrimonio heterosexual, también es aplicable al derecho mismo de contraer: es decir que el hombre y la mujer tienen un derecho igual a contraer matrimonio o lo que es lo mismo que el sexo no justifica desigualdad alguna en el ejercicio de ese derecho. Desde luego ésa es una interpretación posible y tan plausible, si nos atenemos al criterio de la interpretación literal, como la mantenida en el recurso de inconstitucionalidad del PP, que entiende que se refiere, no a la igualdad en la titularidad y ejercicio del derecho al matrimonio, sino en la igualdad dentro del matrimonio heterosexual.

Es perfectamente razonable pensar que el legislador constituyente estuviera pensando en el matrimonio heterosexual y que ni siquiera se le hubiera pasado por la cabeza pensar en el matrimonio homosexual, aunque algún parlamentario aludió a él en los correspondientes debates, pero la literalidad de las expresiones utilizadas no descarta en términos absolutos la posibilidad de su aplicación también a matrimonios homosexuales.

Puesto que se trata de una duda objetiva, fundada en la falta de univocidad de la expresión literal constitucional, habrá que recurrir al resto de las reglas de interpretación del art. 3.1 del CC.

Ahora bien, es preciso tener muy claro que lo que se busca es la voluntad de la ley no la voluntad del legislador a diferencia de lo que ocurren el Derecho canónico ${ }^{44}$ como consecuencia de que «la atribución del poder legislativo, al igual que de los demás poderes jurisdiccionales» en Derecho canónico tiene lugar «de una forma unitaria, a través del sacramento del orden episcopal a unas personas singulares en cuanto tales» ${ }^{45}$. En el Derecho secular la voluntas legislatoris no es más que uno de

44 MÖRSDORF, K., Kirchenrecht, I Band, Enleitung, Allgemeiner Teil und Personenrecht, Ferdinad Scho ningh, München-Paderborn-Wien, 1964, pp. 107 y ss.

45 LlAMAZARES FERNÁNDEZ, D., Derecho Eclesiástico del Estado. Derecho de la Libertad de Conciencia, $2^{\mathrm{a}}$ ed., Madrid, 1991, p. 315. 
los criterios a utilizar para descubrir la verdadera voluntas legis, que pierde fuerza hermenéutica en la medida en que se aleja del momento de nacimiento de la ley.

El primero de los criterios interpretativos enumerados en el art. 3.1 CC, como hemos dicho, no resuelve el problema, porque lo que no está claro es precisamente eso, «el sentido propio de las palabras» en el texto.

Es evidente que históricamente por matrimonio siempre se ha entendido en el Derecho español el matrimonio entre un hombre y una mujer; de manera que si atendemos únicamente a este criterio la duda quedaría, sin más, resuelta.

Lo que no queda resuelto es el tema de los antecedentes del concepto mismo de matrimonio. Su rastreo exige ir más atrás: al matrimonio romano, al canónico y a la tendencia evolutiva del matrimonio civil. Y como apuntamos más arriba, el concepto de matrimonio consagrado en nuestra Constitución, resultado de esa evolución histórica, tiene mucho que ver con la respuesta que pueda darse a la pregunta de si la Constitución deja abierta o no la posibilidad de la evolución del concepto de matrimonio en esta dirección.

No es menos verdad, además, que el sentido propio de las palabras en el contexto o interpretación sistemática, apunta también al mismo resultado.

Sólo aludiré a dos datos que nos ofrece la propia Constitución.

El art. 39, tal como ha sido interpretado por el Tribunal Constitucional, al equiparar todo tipo de familias, también las no nacidas del matrimonio (matrimonios de hecho $)^{46}$, e incluso las constituidas por parejas de homosexuales ${ }^{47}$, parece apuntar hacia una respuesta positiva. Todavía es más significativa la afirmación del TC de «la plena constitucionalidad del principio heterosexual como calificador del vínculo matrimonial, tal y como prevé nuestro código civil» ${ }^{48}$, ya que, como señala agudamente MURILLO MUÑOZ, la frase está suponiendo que es competencia del legislador ordinario optar por ese principio como exclusivo o no ${ }^{49}$. Nada se opone, desde el punto de vista de la Constitución, a la modificación de esa opción legal.

46 STC 47/1993, FJ 3, párr. 2, in fine: «La Constitución no sólo protege la familia que se constituye mediante el matrimonio, aunque a ésta se la proteja especialmente (STC 45/1998), sino también a la familia como realidad social, entendida por tal la que se constituye voluntariamente, mediante la unión de hecho, afectiva y estable, de una pareja»; se reitera el criterio de la STC 222/1992, FJ 5, párr. 1.

47 STC 222/1994, de 11 de julio, FJ 2, párr. 6: «se debe admitir la plena constitucionalidad del principio heterosexual como calificador del vínculo matrimonial, tal como prevé nuestro Código civil; de tal manera que los poderes públicos pueden otorgar un trato de privilegio a la unión familiar constituida por hombre y mujer frente a una unión homosexual. Lo cual no excluye, que por el legislador se pueda establecer un sistema de equiparación por el que los convivientes homosexuales puedan llegar a beneficiarse de los plenos derechos y beneficios del matrimonio, tal como propugna el Parlamento Europeo». ATC 222/1994, FJ 2, párr. 6.

49 Matrimonio y convivencia en pareja..., cit., p. 419. 
Como veremos detenidamente más adelante, la conexión constitucional entre libertad de conciencia, identidad personal e identidad y orientación sexual inclinan claramente la balanza en ese mismo sentido ${ }^{50}$.

A diferencia de lo que acontece en Derecho canónico, donde los criterios de interpretación se han de aplicar en un orden determinado, no debiendo pasar al siguiente si con los anteriores o con alguno anterior se ha resuelto el problema ${ }^{51}$, en Derecho civil no existe tal orden jerarquizado y, consecuentemente habrá que seguir aplicando los criterios aludidos a continuación en el código civil: realidad social del tiempo al que las normas han de ser aplicadas «atendiendo fundamentalmente» a su «espíritu y finalidad» (art. 3.1 CC).

Es la aplicación de la combinación de estas dos últimas reglas la que da un verdadero vuelco a la interpretación a la que nos conducen inequívocamente los antecedentes históricos y legislativos. Se trata de las reglas interpretativas decisivas, incluso, cuando las otras técnicas interpretativas aplicadas aportan datos en uno u otro sentido: lo decisivo es el fin y el espíritu de la ley en relación con la realidad social a la que se aplican, o lo que es lo mismo con los problemas reales que la norma pretende resolver.

Basta tener en cuenta el grado de transformación y de secularización ${ }^{52}$ experimentada por la sociedad española desde el momento en que se elaboró la Constitución hasta el momento actual.

Alguien ha dicho que nunca una Constitución diciendo literalmente lo mismo significa lo mismo; la razón está justamente en el cambio social; ni son las mismas las preguntas que la realidad social le dirige a la ley, ni son los mismos los problemas que exigen respuesta teniendo en cuenta el espíritu y finalidad de la ley, ni por tanto son las mismas las respuestas posibles.

Como apunta MURILLO MUÑOZ ${ }^{53}$, esta idea no está ausente del informe del Consejo de Estado sobre el Proyecto de Ley que introduce la posibilidad de la admisión del matrimonio homosexual al fundamentar su rechazo actual en el riesgo

50 LLAMAZARES FERNÁNDEZ, D., Derecho Eclesiástico del Estado..., cit., pp. 353 y ss.

51 LLAMAZARES FERNÁNDEZ, D., Derecho eclesiástico del Estado, cit., pp. 320-321; Se distingue en el Derecho canónico entre una regla fundamental «sentido de las palabras en el texto y en el contexto» y reglas auxiliares y dentro de ellas, las de carácter general y las de carácter especial y esa distinción es la que marca el orden en que han de aplicarse; ver MÖRDORF, K., Kirchenrecht, I, cit., pp. 108-111.

52 PÉREZ-AGOTE, A. y SANTIAGO GARCÍA, J. A., La situación de la religión en España a principios del siglo XXI, CIS, Centro de Investigaciones Sociológicas, Madrid, 2005; COMAS ARNAU, D., «El proceso de secularización en la España democrática», en Laicidad y Libertades. Escritos Jurídicos, núm. 4, 2004; del mismo, «Pluralismo moral y religioso en la España actual», en Libertad de conciencia y Laicidad en las Instituciones y Servicios Públicos, Cátedra de «laicidad y Libertades Públicas» de la Universidad Carlos III de Madrid, Dykinson, Madrid, 2005; DÍAZ-SALAZAR, R. y GINER, S., Religión y sociedad en España, Centro de Investigaciones Sociológicas, Madrid, 1993.

Matrimonio y convivencia en pareja..., cit., pp. 404-405. 
de que haga irreconocible la institución matrimonial, de acuerdo con la imagen que de la misma tiene la conciencia social de cada tiempo y lugar, al decir del $\mathrm{TC}^{54}$.

El concepto de garantía institucional, por el que en esta sentencia opta el TC, erosiona hasta pulverizarla la base del argumento que pretende oponer frente a ella justamente el carácter de garantía institucional con el que viene privilegiado por la Constitución el matrimonio, como hacen el recurso de inconstitucionalidad presentado por el PP contra la Ley 13/2005 y el Consejo del Poder judicial en el Estudio elaborado motu proprio sobre el proyecto de ley.

Porque la garantía institucional tal como la entiende el Tribunal Constitucional se refiere únicamente a la imagen que de la institución que conserva los elementos esenciales y nucleares que hacen reconocible la institución, pero bien entendido que esa imagen responde a una determinada conciencia de una sociedad concreta en un momento determinado.

\section{Transexualidad y matrimonio civil}

Sorprendentemente en las discusiones en torno al tema, previas a la aprobación de la L. 13/2005 no se hacía referencia ni por unos ni por otros al tema, cuando menos colindante, del matrimonio de los transexuales. Tan sólo después, se hace alusión a él en el recurso de inconstitucionalidad contra la ley presentado por el PP, que parece haber apreciado la posibilidad de que la similitud pueda esgrimirse como argumento para defender la identidad de trato jurídico entre ambos supuestos.

54 STC 32/1981 de 28 de julio, FJ 3: «El orden jurídico-político establecido por la Constitución asegura la existencia de determinadas instituciones, a las que se considera como componentes esenciales y cuya preservación se juzga indispensable para asegurar los principios constitucionales, estableciendo en ellas un núcleo o reducto indispensable por el legislador. Las instituciones garantizadas son elementos arquitecturales indispensables del orden constitucional y las normaciones que las protegen son, sin duda, normaciones organizativas, pero a diferencia de lo que sucede con las instituciones supremas del Estado, cuya regulación orgánica se hace en el propio texto constitucional, en éstas la configuración institucional concreta se defiere al legislador ordinario, al que no se fija más límite que el del reducto indisponible o núcleo esencial de la institución que la Constitución garantiza. Por definición, en consecuencia, la garantía institucional no asegura un contenido concreto o un ámbito competencial determinado y fijado de una vez por todas, sino la preservación de una institución en términos reconocibles para la imagen que de la misma tiene la conciencia social en cada tiempo y lugar. Dicha garantía es desconocida cuando la institución es limitada, de tal modo que se la priva prácticamente de sus posibilidades de existencia real como institución para convertirse en un simple nombre. Tales son los límites para su determinación por las normas que la regulan y por la aplicación que se haga de éstas. En definitiva, la única interdicción claramente discernible es la de la ruptura clara y neta con esa imagen comúnmente aceptada de la institución que, en cuanto formación jurídica, viene determinada en buena parte por las normas que en cada momento la regulan y la aplicación que de las mismas se hace». 
Efectivamente a primera vista parece que aunque haya cierta semejanza, desde luego no se da igualdad. Pero sólo a primera vista. Veámoslo.

La transexualidad ${ }^{55}$ entraña una contradicción entre la apariencia sexual externa y la vivencia interna que esa persona tiene de su identidad sexual: es hombre y se siente mujer o a la inversa. La tensión producida por esa disociación ha conducido en no pocos casos a la mutilación o incluso al suicidio.

Pues bien, nuestro Derecho ha ido modificando su respuesta a los problemas planteados por los transexuales:

$1^{\circ}$ ) En un primer momento la operación quirúrgica destinada a cambiar la apariencia de una determinada sexualidad externa para hacerla acorde con la vivencia interna era tipificada como un delito de mutilación en el CP, responsabilizando de él tanto al transexual operado como al personal sanitario que hubiera intervenido en la operación.

$2^{\circ}$ ) Ésa sería la primera modificación de actitud del derecho ante la transexualidad: excluir de su tipificación como delito la operación quirúrgica destinada a armonizar apariencia externa y vivencias internas de la propia sexualidad.

$3^{\circ}$ ) La reclamación siguiente de los transexuales fue que se reconociera civilmente su cambio de sexo, haciéndole constar en el Registro civil.

En nuestro país el problema lo resolvió no la Ley sino la jurisprudencia. Aunque no sin dificultades y con zigzagueos, el Tribunal Supremo terminó aceptando esa pretensión $^{56}$, que la DGRN hace suya siempre que se hubieran cumplido dos condiciones previas: la operación quirúrgica y sentencia firme aceptando el cambio de $\operatorname{sexo}^{57}$.

Lo más importante en la decisión del TS es que toma como base de su argumentación el art. 10.1 CE entendiendo que el cambio de sexo es expresión del derecho al libre desarrollo de la personalidad, lo que implícitamente equivale a una configuración del derecho al cambio de sexo como contenido de un derecho fundamental.

55 Sobre el tema LÓPEZ GALIACHO, J., La problemática jurídica de la transexualidad, Madrid, 1998; GAVIDIA SÁNCHEZ, J. V., «Uniones homosexuales y concepto y concepto constitucional de matrimonio», en Revista Española de Derecho Constitucional, núm. 61, enero-abril, 2001; LLAMAZARES CALZADILLA, M. C. y PARDO PRIETO, P., «Transexualidad y derecho a contraer matrimonio en España hoy: ¿una luz al final del túnel», en Derecho de familia y libertad de conciencia en los países de la Unión Europea y el Derecho comparado (Ed. CASTRO JOVER, A.), San Sebastián, 2001; TORRES GUTIÉRREZ, A., «Tribunal europeo de derechos humanos: sentencias Christine Godwin v. Reino Unido e I. Reino Unido», en Laicidad y Libertades. Escritos Jurídicos, núm. 3, 2003, pp. 704 y ss.

56 SSTS de 15 de julio de 1988, FJ 10, d) y FJ 13, d); de 15; de 3 de marzo de 1989, FJ 3 in initio.

57 Resolución de 11 de mayo de 1995, FJ 2. 
$4^{\circ}$ ) Inconsecuentemente con ese punto de partida, según nuestra opinión, nuestro TS no extrae de ahí la consecuencia de admitir al matrimonio a los transexuales operados y que han cambiado de sexo aparente, argumentando que se ha cambiado la apariencia pero no la realidad cromosómica. Según el TS esa admisión implicaría que dos personas en realidad del mismo sexo, pero con apariencias sexuales distintas, pudieran ser admitidas al matrimonio heterosexual.

Más consecuente con el punto de partida del TS, la DGRN en los supuestos que han sido sometidos a su consideración ha considerado completamente legales los matrimonios de un transexual con persona de idéntico sexo cromosómico o biológico, pero de distinto sexo legal ${ }^{58}$.

$5^{\circ}$ ) El TEDH también se ha pronunciado sobre esta cuestión en cuatro ocasiones reiterando siempre la misma solución: no a los matrimonios entre dos personas del mismo sexo biológico o cromosómico aunque tengan distinto sexo legal. Pero esta jurisprudencia reiterada cambió bruscamente en dos sentencias de 11 de julio de 2002 que condenan al Reino Unido por no admitir al matrimonio a esas personas $^{59}$, consciente del cambio y razonando el cambio ${ }^{60}$.

Es verdaderamente sorprendente la frivolidad del recurso de inconstitucionalidad presentado por el PP en su referencia a estas dos sentencias para despacharlas alegremente y no tenerlas en cuenta, ya que los cambios de posición del Tribunal, se dice en el recurso, no se refieren a un cambio de concepto de matrimonio, que se supone heterosexual, sino a la concurrencia de los requisitos exigidos para que se pueda hablar de un verdadero cambio de sexo.

No alude, en cambio, el recurso a otras afirmaciones del Tribunal como las siguientes:

$1^{\text {a) }}$ «El Tribunal debe tener en cuenta la evolución de la situación en el Estado demandado...» y «es de crucial importancia que el convenio sea interpretado y aplicado de forma que conceda unas garantías concretas y efectivas y no teóricas o ilusorias». De ahí la necesidad de que el Tribunal mantenga un «enfoque dinámico y evolutivo» ya que de lo contrario su actitud "podría constituir un obstáculo a toda reforma o mejora» ${ }^{61}$.

$2^{a}$ ) La solución dada por el Tribunal en los cuatro casos anteriores «procedía, según el caso, del razonamiento según el cual el derecho a casarse aludía al matrimonio tradicional» ${ }^{62}$.

$3^{\mathrm{a}}$ ) «La dignidad y la libertad del hombre son la esencia misma del Convenio» (...) «en el que la noción de autonomía personal refleja un principio importante que subyace en la interpretación de las garantías de dicha disposición, la esfera

\footnotetext{
${ }^{58}$ Resoluciones de 8 de enero de 2001, FJ 4; Resolución de 31 de enero de 2001.

${ }^{59}$ I. V. Reino Unido y Godwin v. Reino Unido.

${ }^{60}$ FJ 56

${ }^{61}$ FJ 56.

${ }^{62}$ FJ 76.
} 
personal de cada individuo está protegida, incluido el derecho de cada uno a establecer los detalles de su identidad de ser humano» ${ }^{63}$.

$4^{\mathrm{a}}$ ) «La incapacidad para una pareja de concebir o criar un hijo no puede en sí misma privarle del derecho» a «casarse y fundar una familia» ${ }^{64}$.

$5^{\text {a) }}$ «La institución del matrimonio se ha visto profundamente transformada por la evolución de la sociedad y los progresos de la medicina y de la ciencia» ${ }^{65}$.

$6^{\text {a) }}$ «El Tribunal constata también que el texto del art. 9 de la carta de los derechos Fundamentales de la Unión europea adoptada recientemente se aparta -y ello no puede ser sino deliberado- del art. 12 del Convenio en cuanto que excluye la referencia al hombre y a la mujer» ${ }^{66}$.

De cara al matrimonio, se difumina cada vez más la importancia de la diversidad sexual, ya que deberían tenerse en cuenta otros múltiples factores de cara al objetivo fundamental de la vida en pareja como marco para el desarrollo libre de la personalidad de cada uno de los miembros de la pareja en orden a la consecución de un mayor grado de felicidad.

\section{Moral pública y matrimonio}

Ése es el caso, en mi opinión, de la modificación del Código civil a la que nos venimos refiriendo. El Parlamento lo único que ha hecho es abrir la posibilidad de acceso a él de las parejas homosexuales, algo que no es otra cosa que reconocerles el ejercicio de un derecho, el derecho de contraer matrimonio entre sí, que antes no tenían.

No existe norma alguna en la moral pública, tal como la venimos describiendo que considere esto como prohibido. Buena prueba de ello es que ningún partido del arco parlamentario, por ejemplo, se ha opuesto a la regulación de lo que se ha dado en llamar uniones civiles sobre la base de la moral pública. Es más, la derecha lo ha propuesto como alternativa. No se alcanza a ver por qué sí colisionaría con esa moral el acceso de los homosexuales al matrimonio, dada la identidad de ambos supuestos como parejas de convivencia more uxorio.

\section{Libertad de conciencia, orientación sexual y matrimonio civil}

De todo cuanto venimos diciendo se desprende como insoslayable la respuesta a la pregunta ¿por qué no? Porque ése es el cambio metodológico al que inexorablemente nos obligaba la presunción a favor de los derechos de la persona y la interpretación restrictiva de sus límites, especialmente si tienen rango constitucional y están inmediatamente conectados con derechos fundamentales. No hay razones insuperables que se opongan a una respuesta positiva. Ahora ha llegado el momento de formularnos la pregunta de ¿por qué sí?

\footnotetext{
${ }^{63} \mathrm{FJ} 72$.

${ }^{64} \mathrm{FJ} 80$.

${ }^{65} \mathrm{FJ} 82$.

${ }^{66}$ Ibidem, último inciso.
} 
Demostrado que no hay razones que se opongan a una respuesta positiva, vamos a ver si el texto constitucional nos aporta elementos que nos permitan afirmar que, si no la única constitucionalmente posible, la afirmativa es, no sólo congruente, sino la más congruente con la Constitución y probablemente la única congruente con ella en el momento actual de nuestra sociedad.

\subsection{Libertad de conciencia e identidad personal}

La conciencia ${ }^{67}$ es la fuente original de la personalidad, si entendemos por esta expresión, la percepción de «sí mismo» o lo que es igual, de aquello que se percibe como inseparable e irrenunciable de uno mismo, de lo singular y diferente, como potencialidad que incluye facultades y límites y que permite ver ese «sí mismo» como referente y sujeto de la propia historia, de lo que uno hace y de lo que le hacen o de lo que le acontece; todo ello con un telón de fondo: la persona digna, propuesta por el art. 10.1 como modelo a seguir, horizonte asintótico del libre y pleno desarrollo de la personalidad y fuente de las normas reguladoras de nuestras conductas y del ejercicio de la libertad como auténticos imperativos categóricos.

La conciencia es la fuente de nuestro conocimiento, de la ciencia, pero también de la moral, de la Ética ${ }^{68}$ como saber sobre la moral. Todo ese conjunto de creencias, convicciones, ideas y sentimientos constituyen la «cosmovisión» personal.

«Mismidad» e identidad personal son la misma cosa. La conciencia es la causa de que la persona perciba todo eso que le define y que, en definitiva, constituye su identidad personal: el núcleo duro de sus convicciones creencias e ideas (en el sentido de ideales) más íntimas e inseparables de su personalidad.

Al desarrollo libre de esas potencialidades más profundamente enraizadas en el yo es a lo que se refiere el art. 10.1 cuando habla como expresión primera de la dignidad personal, del «libre desarrollo de la personalidad».

Sólo sobre la base de esa percepción puede la persona disponer de criterios que le permitan decidir sobre lo que tiene que hacer incondicionadamente para alcanzar su máximo desarrollo posible ("pleno” en expresión del art. 27.2 CE); lo cual incluye la percepción, tanto de las posibilidades como de los límites; es más, por referencia a ese núcleo, que incluye el ideal de persona, estará en condiciones de disponer de criterios que le permitan reaccionar de la forma más correctamente posible, en orden al mismo objetivo, con respecto a lo que le acontece y a las influencias de las acciones de los otros sobre él.

67 Sobre el concepto de conciencia LLAMAZARES FERNÁNDEZ, D., Derecho de la Libertad de Conciencia, I, $2^{\text {a }}$ ed., pp. 17-28; ver también TARODO SORIA, S., La libertad de conciencia y los derechos de los usuarios de los servicios sanitarios, Universidad del País Vasco, Bilbao, 2005, pp. 37 y ss.

68 Sobre la distinción entre Ética y Moral TARODO SORIA, S., Libertad de conciencia y derechos del usuario de los servicios sanitarios, cit., pp. 48-52. 
La conciencia es aquí lo fundamental. La autopercepción es aquí lo decisivo. Lo que no puede uno es ser incoherente con esa autopercepción, so pena de cerrar las puertas a la posibilidad misma de alcanzar su más alto nivel de desarrollo posible como persona moral y ser espiritual. Sólo la coherencia de lo que se hace con lo que se dice y con lo que se cree marca el buen camino.

\subsection{Identidad personal, orientación sexual e identidad sexual}

Uno de los elementos identificadores de la persona que, por ello, forma parte integrante de la identidad personal es, de acuerdo con nuestro Derecho, la identidad sexual e incluso la orientación sexual ${ }^{69}$.

El homosexual, por tanto, tiene derecho a su libre desarrollo como homosexual; como lo que es, no como lo que no es; antes por lo que se siente, incluso, que por lo que sólo aparentemente se es.

Lo hemos dicho: lo decisivo, desde el punto de vista de la realización personal, no es lo que biológicamente se es, sino lo que uno «se siente» ser. Algo que vale tanto para los transexuales como para los homosexuales con vistas a la vida en pareja.

No parece discutible lo primero: la identidad sexual forma parte de la identidad personal. El problema, como veíamos cuando nos hemos referido a los transexuales, es si lo que forma parte de la identidad personal es el sexo aparente o el cromosómico, el sexo «psíquico», «vivido y sentido», o el «orgánico» y "biológico”.

Si el punto de partida obligado constitucionalmente es el libre desarrollo de la personalidad con base en la conciencia como «consciencia», fuente de conocimiento de «lo que es» (ciencia) y de lo que «debe ser» (moral), la respuesta inmediata parece imponerse: desde ese punto de vista: lo que importa es lo que se «vive» y se «siente», no lo que «orgánicamente aparece». Desde el punto de vista de la personalidad y su libre desarrollo, en realidad, se es lo que se «vive» y se «siente».

Pero esto mismo vale para los homosexuales. También la homosexualidad es un problema de «sentimientos» y de «vivencias» sobre la base de la autopercepción íntima. El homosexual se siente atraído para formar vida en pareja, no por personas del otro sexo, sino por otras personas del mismo sexo. Y eso es lo que cuenta desde el punto de vista de la conciencia. Porque sólo en ese tipo de pareja encuentra acomodo para el «libre desarrollo de su personalidad».

69 VIDAL GALLARDO, M., «El derecho a la identidad sexual como manifestación del derecho a la identidad personal», en Laicidad y Libertades. Escritos Jurídicos, núm. 3, 2003. 


\subsection{Libertad de conciencia, identidad personal, orientación sexual y convivencia en pareja}

La convivencia en pareja tiene como objetivo fundamental facilitar el «libre desarrollo de la personalidad» de cada uno de los miembros de la pareja, alimentando, siquiera sea en la fugacidad del instante, la llama de la felicidad.

No otra cosa significa la protección jurídica que nuestra Constitución (art. 39) dispensa a las familias, también a las parejas, no nacidas ni formalizadas como matrimonio, incluidas las homosexuales, dejando abierta la puerta, según el Tribunal Constitucional, a su equiparación jurídica a las parejas matrimoniales ${ }^{70}$.

¿Dónde está la diferencia constitucional, entonces? ¿Es sólo de nombre? En opinión del TC sólo queda una diferencia: ¿en ningún caso se puede dar un trato privilegiado a las parejas de hecho en relación con la dispensada al matrimonio, pero constitucionalmente sí vale la inversa? ${ }^{71}$

\subsection{Libertad de conciencia y matrimonio}

Desde el punto de vista del derecho de libertad de conciencia y del libre desarrollo de la personalidad, no es lo mismo la unión en pareja que la unión en matrimonio. La primera no puede alcanzar la situación de privilegio que constitucionalmente está abierta para la segunda. No es verdad, por tanto, que en ambos casos sean equiparables las condiciones de los miembros integrantes de cara a su desarrollo

\section{ATC 222/1994.}

STC 184/1990, de 15 de noviembre FJ 2, párr. 2: «Por ello no serán necesariamente incompatibles con el art. 39.1 CE aquellas medidas de los poderes públicos que otorguen un trato distinto y más favorable a la unidad familiar basada en el matrimonio que a otras unidades convivenciales, ni aquellas otras medidas que faciliten o favorezcan el ejercicio del derecho constitucional a contraer matrimonio (art. 32.1 CE), siempre, claro es, que con ello no se coarte ni se dificulte irrazonablemente al hombre y la mujer que decidan convivir more uxorio. Decisión ésta libremente adoptada por los sujetos de la unión de hecho y que diferencia el supuesto constituido por las medidas que afectan sólo a los integrantes de dicha unión respecto de otras previsiones normativas que tienen como destinatarios a los hijos, ya que éstos son iguales ante la ley con independencia de su filiación (art. 39.2 CE) y a los cuales, habidos dentro o fuera del matrimonio, los padres deben prestar asistencia de todo orden (art. 39.3 CE), precisamente, y entre otros motivos, porque su filiación y su condición de habidos dentro o fuera del matrimonio es el resultado de decisiones ajenas a los mismos. Y es, asimismo, diferente aquel supuesto del que se refiere a la necesaria protección de las madres, cualquiera que sea su estado civil (art. $39.2 \mathrm{CE}$ ), ya que en este caso resultan comprometidos otros intereses y valores distintos a los de los solos integrantes de la unión estable de hecho, unión que, por lo demás, en este caso puede perfectamente no existir».

Sin embargo, el razonamiento anterior no conduce a afirmar que toda medida que tenga como únicos destinatarios a los cónyuges, con exclusión de quienes conviven establemente en unión de hecho, sea siempre y en todos los casos compatible con la igualdad jurídica y la prohibición de discriminación que la Constitución garantiza en su art. 14. Criterio que se reiterará en la STC 66/1994. 
personal y que no sufra el principio de igualdad y, consecuentemente el de libertad de conciencia.

Una cosa es que se deje en libertad a las personas para vivir o no vivir en pareja, para hacerlo como una mera situación de hecho o en el marco de una fórmula mínimamente reglada, o finalmente en el marco de la fórmula del matrimonio. Pero sin obligar a optar por una de esas soluciones o impidiendo hacerlo en relación con alguna de ellas. Aquí la función del Derecho se limita a dar normas que canalicen y faciliten el ejercicio del derecho, pero nada más. Otra cosa quebraría la libertad de las conciencias.

No me refiero únicamente a matrimonios heterosexuales, sino también a matrimonios entre homosexuales.

Porque la felicidad en pareja no depende de la diferencia sexual, sino de la atracción amorosa en la que aflora la oportunidad de ejercitar la propia libertad en el grado supremo, como ejercicio de autodisposición en el doble movimiento recíproco de entrega al otro y de aceptación del otro. Y este mutuo y recíproco movimiento de salida de sí mismo hacia el otro, en actitud de abierta acogida o de generosa entrega, es posible, con una u otra intensidad, allí donde hay atracción simultáneamente sexual, afectiva y amorosa, con independencia de que las personas tengan diferente o idéntico sexo.

No sólo no es constitucionalmente contradictorio. Es constitucionalmente lo más congruente.

Resumiré el argumento principal.

Eso que llamamos identidad personal no es otra cosa que el conjunto de convicciones (ideas e ideales, más sentimientos) sobre uno mismo, así como de las relaciones con lo otro y con los otros, resultado de la autopercepción emocional como ser en parte diferente y en parte similar a los demás y a lo demás, y con la posibilidad de varias alternativas de respuesta a los estímulos externos, como referente de mis acciones, de lo que me acontece y de lo que hago, de mi propia historia, de mis posibilidades y de mis límites.

Es a este punto de partida al que se refiere el art. 10.1 de nuestra Constitución, con expresiones tales como «dignidad de la persona» y «libre desarrollo de la personalidad».

La dignidad de la persona se apoya justamente en esas dos columnas: capacidad para la autopercepción y capacidad para la libertad, en acto o en potencia, sobre la base de la presunción de los artículos 29 y 30 del código civil; para, a base de decisiones, ir superando las propias limitaciones hasta alcanzar el máximo desarrollo personal posible en consonancia con las propias potencialidades.

Ése es el parámetro ético de nuestras decisiones que a través del proceso dialogal y de la norma kantiana de considerar norma de conducta personal sólo la que 
consideremos de aceptación por todos los demás que, en virtud de esa aceptación, puede convertirse en norma ética universal.

En esa percepción de sí mismo la persona se topa con los otros y, no sólo con lo que le diferencia de ellos, sino también con aquello en lo que coincide y que comparte con ellos; de donde el sentimiento de solidaridad; es más, la vivencia de la necesidad de los otros para enriquecer las posibilidades de autodesarrollo: de la necesidad de la convivencia en general, en primer lugar, pero también de determinados modelos de convivencia.

Uno de esos modelos de convivencia privilegiados es, a la vista de las experiencias y vivencias fenomenológicas, la convivencia en pareja, en especial la convivencia que tiene su base en el sentimiento del amor, o para entendernos, la convivencia more uxorio en la que el amor como ágape contiene y es alimentado por la atracción afectiva (eros) y por la sexual.

El artículo 32. 1 CE responde al principio de que el matrimonio, como convivencia more uxorio está al servicio de la persona y de su derecho al libre desarrollo y no al contrario, de un lado; de otro, la ciencia ha hecho posible la total separación de la unión sexual y de la procreación, idea que corrobora la relación entre el art. 32 y el art. 39, como afirma PANTALEÓN ${ }^{72}$ que añade «si no perjudica más que al símbolo, yo creo que conviene que el símbolo no sirva para sacrificar en su altar a seres humanos (...) Ahora (1990) no hay obligación constitucional de permitir la institucionalización de la pareja, pero puede llegar a haberla, conforme se va desenganchando en la conciencia social matrimonio de procreación; cada vez hay más razones de artículo 14 que oponer al art. 32 (...) y sin duda llegará un momento en el que en la conciencia social la convivencia homosexual reclame la equiparación; y entonces será discriminatorio no hacerlo».

La institución matrimonial no tiene sentido por sí misma, sino sólo en función de las personas que integran la pareja y sólo subsidiariamente de la sociedad. Se ha producido un cambio radical con el pasado en el que el principio era justamente el inverso; una concepción que todavía se conserva, en sus líneas esenciales, en el Derecho canónico y su concepción del matrimonio como sacramento.

Mediante la integración del sexo en el eros y de ambos en el ágape, por la correspondencia de reciprocidad que elimina la posibilidad de la enajenación, es teóricamente posible alcanzar un clímax de entrega y aceptación interpersonal supremo, aunque sea en efímeros instantes (Yo-Tú-Nosotros) ${ }^{73}$. Es la apertura esencial de la persona a otras personas; es decir, el supremo ejercicio de la libertad, ya que nunca se ejercita en grado máximo la libertad, como expresión de autodominio, mas que cuando se dispone de uno mismo en actitud simultánea de

72 «Régimen jurídico civil de la uniones de hecho» en Uniones de hecho (Dir. MARTINELL, J. M. y ARECES PIÑOL, M. T.), Lleida, 1998, p. 70.

73 LLAMAZARES FERNÁNDEZ, D., Derecho de la Libertad de Conciencia, II, cit., pp. 353 y ss.; también en Sistema matrimonial español, cit., pp. 8-9; MURILLO MUÑOZ, M., Matrimonio y convivencia en pareja..., cit., pp. 40 y ss. 
donación y aceptación; todo lo cual pone de relieve que ése es un marco apropiado, no necesariamente el único, de realización de la libertad como entrega y como aceptación personales.

Es necesario subrayar que la totalidad e incondicionalidad de la entrega y de la aceptación que dan vida a un nuevo centro existencial de decisión, aunque sea efímera, no es concebible si no es en el seno de la pareja. No parece concebible ni en la poliandria ni en la poliginia como modelos de convivencia more uxorio.

Ésa sería la utopía ideal a la que pretende responder el modelo matrimonial canónico indisoluble, por ejemplo, y que se traduce en los ordenamientos laicos en un modelo más realista, consciente de las limitaciones humanas, asentado, eso sí, sobre el mutuo consentimiento constantemente renovado (permanencia del affectus maritalis).

La pregunta que hay que hacerse es si sólo es posible encajar en este modelo de convivencia more uxorio la convivencia en pareja heterosexual o si también es subsumible, sin violencias, el modelo de convivencia homosexual.

Como es sabido el principio básico de nuestro sistema de convivencia es la dignidad de la persona humana sobre la base de dos columnas: la libertad de conciencia del 16.1 y de la igualdad del 14 en relación con el 9.2.

La orientación sexual no puede ser razón para la desigualdad ni para la discriminación. Es más, la orientación sexual es considerada como un elemento integrante de la identidad personal, en tanto que derecho fontal y básico. De ahí la especial protección de la que disfrutan los datos referidos a ideología, religión o creencias (art. 16.2 CE y art. 7.1 LOPDCP), o en especial a la vida sexual (art. 7.3 LOPDCP) o la protección penal de la orientación sexual respecto a tratamientos discriminatorios, denigrantes, difamatorios, o que provocaren odio o violencia contra esas personas o grupos con denegación, por funcionario o particular, de prestaciones a las que tengan derecho, como consecuencia de su orientación sexual, bajo la rúbrica general de delitos relativos al ejercicio de los derechos fundamentales y libertades públicas: de los delitos cometidos con ocasión del ejercicio de los derechos fundamentales y de las libertades públicas garantizados por la Constitución (arts. 510 y ss. del CP).

El homosexual, por tanto tiene derecho al «libre desarrollo de su personalidad», también en cuanto homosexual, ya que la homosexualidad forma parte integrante de su identidad personal, es decir, de su personalidad.

El derecho al matrimonio es un derecho, no fundamental, pero sí constitucional, del que son titulares todas las personas con capacidad para la entrega y aceptación interpersonales en una relación more uxorio capaz de integrar esos tres niveles del sexo, el eros y el ágape, con independencia de la capacidad o no capacidad para la generación, como pértiga hacia la felicidad. 
Si el matrimonio, como derecho constitucional, disfruta de un grado de protección jurídica privilegiada correspondiente a la garantía institucional, sólo en base a sólidas razones se puede negar el acceso a él a unos ciudadanos que como tales son titulares de todos los derechos fundamentales, también del de igualdad. Más aún, como vimos esa protección no alcanza únicamente al matrimonio heterosexual cuando la imagen que del matrimonio tiene la sociedad ha cambiado tanto que incluye en ella también al matrimonio homosexual.

Me parece un argumento muy endeble afirmar que el problema tiene solución abriendo a los homosexuales la posibilidad de la unión civil que les ofrecería los mismos derechos con equiparación total, para no desnaturalizar el matrimonio tradicional, sacrificando los derechos de la persona en aras de la institución, sin otro apoyo que la defensa del nombre. La igualdad, dada esa protección jurídica especial a la que hemos aludido, no se consigue por esta vía, salvo que estemos incurriendo en una logomaquia; y, de otra parte, me parece una solución más bien hipócrita e incluso cínica, desde un punto de vista ético.

Así las cosas, parece que estamos ante un derecho, según este razonamiento, que tiene por objeto también la formación de pareja del mismo sexo, si queremos soslayar la cruel injusticia de negar la apertura a la felicidad, siquiera sea recortada, a las personas con orientación homosexual, que consideramos parte integrante de la identidad personal, incurriendo, de paso, en una burda y clamorosa contradicción y en una no menos escandalosa violación del derecho de igualdad.

Dos son las conclusiones fundamentales:

$1^{a}$ ) No hay ninguna razón que impida optar por esa solución: es posible otra interpretación de la Constitución; no lo impide la moral pública que es la única que ha de funcionar como parámetro de la injusticia o de la justicia de las decisiones de los poderes públicos; ni la garantía institucional del matrimonio ya que según el TC dada su dependencia de la imagen social del matrimonio y, por tanto, no inmutable sino susceptible de evolución y diferenciación según tiempos y lugares; ni la diferencia sexual de los miembros de la pareja o heterosexualidad es algo absolutamente necesario desde el punto de vista de los Derechos Humanos, separadas sexualidad y procreación.

$\left.2^{a}\right)$ El respeto del derecho de libertad de conciencia como base de la identidad personal que incluye tanto la identidad sexual como la orientación sexual, y de las normas morales exigidas por la dignidad personal y sus valores de realización, no solo sortea cualquier suerte de contradicción con el texto constitucional, sino que muestra la respuesta positiva como la más congruente con ese texto en este momento y muy probablemente como obligada, si tenemos en cuenta la evolución de la sensibilidad de nuestra sociedad en relación con los Derechos Humanos, así como en relación con su imagen esencial del matrimonio. 


\section{MATRIMONIO CIVIL Y MATRIMONIO RELIGIOSO}

La relación entre ellos ${ }^{74}$ ha de determinarse desde la perspectiva del derecho de libertad de conciencia y de su garantía, la laicidad del Estado, lo cual implica dos cosas: la total e incondicionada libertad de opción entre ellos, bien de uno solo de ellos, bien de ambos simultáneamente, y la exclusión de cualquier atisbo por parte del ordenamiento del Estado de prestar su coactividad a las normas confesionales con esencial desnaturalización de las mismas y evidente violación de la libertad de conciencia.

Así las cosas, quedan excluidas de mano varias soluciones posibles:

$1^{\text {a) }}$ la que penaliza la celebración religiosa del matrimonio, admitiendo tan sólo el matrimonio civil;

$2^{a}$ ) la que relega al papel de subsidiario a este último para los no creyentes, convirtiendo en el único civilmente posible al religioso, bien uno solo con exclusión de los demás, bien varios según la fe religiosa de los contrayentes, dando el ordenamiento civil plena eficacia, dotándolas de su propia coactividad, a las normas confesionales reguladoras del matrimonio.

De modo que sólo quedarían como compatibles con esos dos principios las dos modalidades siguientes:

$1^{\text {a) }}$ La que asegura la libertad total de elección entre ambos tipos de matrimonio, sin penalizar ninguno, pero sin reconocer ni atribuir efecto jurídico civil alguno al matrimonio religioso (separación total).

$2^{a}$ ) La que asegura igualmente la total libertad de elección entre ambos tipos de matrimonio, incluso la doble celebración, reconociendo al matrimonio religioso efectos civiles como si fuera un matrimonio civil, siempre que ese reconocimiento facilite el ejercicio del derecho de libertad de conciencia y que no entre en contradicción con la laicidad del Estado.

Aunque también en España el proceso secularizador del matrimonio se había iniciado mucho antes, sobre la base de la distinción de insignes canonistas entre contrato y sacramento, con la consiguiente distribución de las competencias correspondientes entre la Iglesia y el Estado, empujado por el regalismo, primero, y las ideas de la ilustración, después ${ }^{75}$, el hito fundamental de ese proceso fue la

74 Sobre las diferencias entre ambos, cfr. SUÁREZ PERTIERRA, G., «Matrimonio civil y matrimonio eclesiástico: dos sistemas jurídicos diversos», en La actualidad jurídica, VIII, 1981.

75 CRESPO DE MIGUEL, L., La secularización del matrimonio, EUNSA, Pamplona, 1992, pp. 7 y ss.; FERNÁNDEZ CORONADO, A., El proceso de secularización del matrimonio, Centro de estudios Políticos y Constitucionales, Madrid, 2004. 
aprobación de la ley de 1870 al amparo de la Constitución de 1869 en la que por primera vez se reconocía el derecho de libertad religiosa ${ }^{76}$.

Esta ley convertía en obligatorio el matrimonio civil, único que tenía efectos civiles (y en este sentido, obligatorio), con una regulación mimética respecto de la canónica, pero atribuyendo la competencia sobre él al Estado, con carácter exclusivo $^{77}$.

Como es sabido, esta ley tuvo una vigencia muy efímera y pocos años más tarde el modelo de matrimonio civil obligatorio sería sustituido por el matrimonio civil subsidiario, configurándose el matrimonio confesional canónico como obligatorio para todos cuantos profesasen la religión católica. El nuevo modelo estuvo vigente hasta la reforma del Título IV del CC con posterioridad a la constitución del 78, con una corta interrupción durante la Segunda República en que cristalizó nuevamente el proceso secularizador, aunque en este caso con una legislación del matrimonio civil alejada de la canónica y con la introducción del divorcio que había sido constitucionalizado como un derecho en el art. 43 de la Constitución.

Por influencia del Concilio Vaticano II, a partir de 1969 se suavizaría en su aplicación la exigencia de prueba de acatolicidad de los contrayentes. Se convirtió así de hecho en un sistema de tipo facultativo. Sobre la base del art. $32 \mathrm{CE}$, el Código civil vigente, en su art. 49 en relación con el 59, ha optado claramente por la segunda de las fórmulas enunciadas: libertad de elección entre matrimonio civil o religioso, atribuyendo a todos ellos los mismos efectos civiles ${ }^{78}$, poniendo como únicas condiciones: $1^{\text {a }}$ ) que la confesión religiosa esté inscrita (no aclara si necesariamente en el Registro de Entidades Religiosas o si es suficiente que lo esté en el Registro General de Asociaciones), y $2^{\mathrm{a}}$ ) que el consentimiento matrimonial se haya prestado en la forma prevista por la confesión en los términos a) acordados con el Estado o, b) en su defecto, autorizados por la legislación de éste.

Entre el modelo anglosajón y el modelo latino, evidentemente nuestro Derecho ha optado por el primero: no varias clases de matrimonio, sino matrimonio único (civil) con pluralidad de formas o, si se prefiere, con libertad de forma de celebración y única clase de matrimonio. Si exceptuamos las normas sobre la forma, las demás son las civiles, comunes a todos los matrimonios, cuyos requisitos de validez y los efectos que se les atribuyen son exactamente los mismos, los señalados por esas normas civiles ${ }^{79}$.

76 CUBILlAS RECIO, M., El sistema matrimonial español y la cláusula de ajuste al Derecho del Estado, Secretaría de Publicaciones de la Universidad de Valladolid, Valladolid, 1985, pp. 123 y ss.

77 DELGADO DEL RÍO, G., El matrimonio en forma religiosa, Palma de Mallorca, 1988, pp. 32-33.

78 LLAMAZARES FERNÁNDEZ, D., El sistema matrimonial español. Matrimonio civil, matrimonio religioso y matrimonio de hecho, Servicio de Publicaciones de la Facultad de Derecho UCM, Madrid, 1995, pp. 13-22.

79 LLAMAZARES FERNÁNDEZ, D., Ibidem, pp. 16-22. 
En este sentido el Código civil debe considerarse como congruente (arts. 49, 56, 59, 60, 73 y 80) de los Acuerdos del 79 con la Iglesia católica que, de conformidad con el texto constitucional, responden a este mismo modelo.

A él responden, también, los Acuerdos de cooperación con FEREDE, FCI y CIE, en los que se reconoce efectos civiles al matrimonio religioso celebrado ante los correspondientes ministros confesionales (pastores, rabinos o imames), con una remisión material a las normas confesionales sobre la forma de celebración en el caso de judíos y musulmanes que, de hecho, quedan vacías de contenido en este último caso por contradicción con normas constitucionales y de orden público del ordenamiento español ${ }^{80}$.

En ninguno de estos tres casos está prevista la posibilidad de reconocimiento de eficacia civil a las resoluciones de las competentes jurisdicciones confesionales.

Existe, en cambio, esa previsión respecto de los católicos, para, en virtud del principio de cooperación, facilitar el ejercicio sin obstáculos de su libertad de conciencia, ya que en razón de sus creencias consideran como únicas autoridades competentes para los católicos en la materia a las religiosas. De ahí que se acepte la posibilidad de que recurran, para la disolución o nulidad de su matrimonio, a esas autoridades jurisdiccionales religiosas, atribuyendo el Estado a sus decisiones eficacia civil sólo si se da plena conformidad, según unos, siempre que no se dé contradicción, según otros, con el Derecho estatal ${ }^{81}$, bien sólo con el Derecho procesal, o también con el Derecho sustantivo, lo que exigiría que el juez civil entrara en el examen de fondo del contenido de la sentencia canónica antes de proceder a su homologación civil.

80 Art. 7.; LLAMAZARES FERNÁNDEZ, D., ibidem, pp. 186 y ss.; MARTINELL, J. M., «Derecho a celebrar ritos matrimoniales y acuerdos de cooperación», en Acuerdos del Estado español con Confesiones religiosas minoritarias, cit., pp. 667 y ss.; DELGADO DEL RÍO, G., El matrimonio en forma religiosa, cit., pp. 55-90; NAVARRO VALLS, R., El matrimonio religioso ante el Derecho español, Servicio de Publicaciones de la Facultad de Derecho UCM, Madrid, 1984, pp. 105 y ss.

Sobre esto cfr. CUBILLAS RECIO, M., El sistema matrimonial español..., cit., pp. 186206 y pp. 270 y ss.; LLAMAZARES FERNÁNDEZ, D., El sistema matrimonial español..., cit., pp. 13-22; FERNÁNDEZ-CORONADO, A., «Sentencia del Tribunal Constitucional 328/1993 de 8 de noviembre. Recurso de amparo 13406/93. Eficacia civil de decisión pontificia sobre dispensa de matrimonio rato y no consumado», en Revista de Derecho Privado y Constitución, núm. 3, 1994; CALVO ESPIGA, A., «Homologación civil de dispensa pontificia "súper rato": notas sobre dos sentencias del Tribunal Constitucional español», en Lumen, núm. 39, 1990, pp. 424-447: el mismo, «El Ordenamiento jurídico español y la homologación civil de las sentencias canónicas de nulidad matrimonial y dispensas pontificias de matrimonio rato y no consumado: el debate parlamentario en torno a la redacción del art. 80 CC», en Scriptorium Victoriense, 41, 1994, pp. 247-325. Para una visión completa del tema cfr. LÓPEZ ZARZUELO, F., El proceso canónico del matrimonio rato y no consumado. Eficacia civil de las resoluciones pontificias, Valladolid, 1991. 
El problema es cómo han de interpretarse las normas del Acuerdo de 1979 con la Iglesia católica y las de nuestro código civil si queremos ser escrupulosamente respetuosos con nuestra Constitución.

El TC ha calificado el reconocimiento de eficacia civil al matrimonio celebrado en forma religiosa y a las sentencias y resoluciones canónicas de nulidad o disolución como supuestos de cooperación del Estado con las confesiones religiosas a la que se refiere el art. 16.3.

Ahora bien, tiene que estar muy claro de qué tipo de cooperación se trata. Porque en esa norma se está haciendo referencia a dos tipos de cooperación muy diferentes: la obligada y la no obligada. Incluso si se entiende la expresión «mantendrán las consiguientes relaciones de cooperación» como un mandato a los poderes públicos, el adjetivo «consiguientes» ya advierte que se trata de distintos tipos de cooperación.

En unos casos es obligada por ser necesaria esa cooperación para hacer reales, efectivas y plenas la igualdad y la libertad religiosas por estar en juego un elemento integrante del contenido esencial del derecho de libertad religiosa.

En otros lo único que está en juego no es posibilitar el ejercicio del derecho, sino simplemente su facilitación: no estamos ante un elemento integrante del contenido esencial del derecho de libertad religiosa.

La LOLR en su art. 2 describe cuáles son los elementos integrantes de ese contenido esencial, entre los que enumera el derecho a «celebrar sus ritos matrimoniales». Lo que no incluye es el derecho a que esa celebración tenga efectos civiles. Con mucha mayor razón no se incluye en ese derecho el reconocimiento de efectos civiles a decisiones de tribunales o autoridades confesionales sobre nulidad o disolución del matrimonio.

En el mismo sentido se ha interpretado por la $\mathrm{CoEDH}^{82}$ el art. 12 del CEDH que, de acuerdo con el art. 10.2 CE ha de tenerse en cuenta al interpretar las normas constitucionales relativas a los derechos humanos: el reconocimiento de efectos civiles al matrimonio religioso no forma parte integrante del contenido esencial del derecho de libertad religiosa.

Se trata, por tanto, de una cooperación constitucionalmente no obligada, como la del núm. 2 del art. 2 de la LOLR (asistencia religiosa), sino de una cooperación constitucionalmente indiferente, $\mathrm{y}$, por tanto, posible, siempre que no entre en contradicción con la igualdad o con la laicidad que, en todo caso son su límite infranqueable.

Es preciso, tener en cuenta, además, las profundas diferencias entre la regulación confesional del matrimonio y su regulación civil informadas por principios muy diferentes, a pesar de lo que pudiera desprenderse de la identidad de términos y

82 CoEDH, Decisión núm. 6167/73. European Commission of Human Rights. Decisions and Reports, Vol. 1, Strasbourg, July, 1975, pp. 64-65. 
expresiones utilizados ${ }^{83}$. El Tribunal civil deberá tener esto muy en cuenta, tanto en relación con el Derecho procesal como con el sustantivo. Ni los criterios de valoración de las pruebas son los mismos, ni el principio de contradicción, de igualdad entre las partes según que defiendan la validez o la nulidad del matrimonio, ni la posición dominante del juez o el derecho a la defensa son iguales. Por poner sólo un ejemplo de Derecho sustantivo, la misma expresión «consentimiento matrimonial» significa dos cosas muy diferentes en uno y otro ordenamiento.

Ese carácter confesional, ausente de las normas estatales, y su consecuencia obligada, la falta de reciprocidad entre ambos ordenamientos matrimoniales que impide que el canónico reconozca las resoluciones civiles de divorcio o de nulidad de las normas canónicas. Algo que cuestiona la posibilidad de aplicar por analogía la norma del Reglamento de la Unión Europea ${ }^{84}$ sobre producción de efectos de las sentencias de nulidad del matrimonio, pronunciadas en cualquiera de los países miembros, en todos los demás (art. 14), sin que pueda negarse tal reconocimiento sobre la base de que el miembro requerido no autorizaría la nulidad basándose en los mismos hechos (art. 18).

A nuestro parecer, teniendo en cuenta las distintas posiciones, depurando el sistema de residuos confesionales ${ }^{85}$ para adecuarlo a la Constitución, los requisitos que debería cumplir una sentencia o resolución canónica para ser civilmente homologada son los siguientes:

1) corrección procesal de la sentencia y cumplimiento, desde este punto de vista, de las condiciones previstas por el art. 954 LEC para el exequatur de las sentencias de tribunales extranjeros ${ }^{86}$;

2) no consolidación de otra solución civil con la que entre en contradicción la sentencia canónica; por ejemplo, porque el defecto causa de nulidad se ha subsanado civilmente, o porque ya ha habido otra sentencia civil de nulidad o divorcio de sentido contrario ${ }^{87}$;

83 Sobre esto ver LLAMAZARES FERNÁNDEZ, D., El sistema matrimonial español..., cit., pp. 27-58 y en Prólogo a VILLAR PÉREZ, A., El acto Interlocutorio: la sentencia y el decreto, Universidad de Valladolid, Valladolid, 1986, pp. 18-23.

84 Un clarificador análisis del Reglamento en RODRÍGUEZ CHACÓN, R., «Unión Europea y eficacia civil de resoluciones matrimoniales canónicas», en Laicidad y libertades, núm. 1, pp. 137-188.

85 Sobre la confesionalidad del anterior sistema matrimonial español, cfr. SUÁREZ PERTIERRA, G., «Incidencia del principio de confesionalidad del Estado sobre el sistema matrimonial español», en Revista Español de Derecho Canónico, 1977.

86 DE DIEGO LORA, C., «La eficacia en el orden civil de las resoluciones eclesiásticas en materia matrimonial», en Ius Canonicum, 37, 1979, pp. 204-209; reitera esta opinión de que el juez civil no debe entrar en cuestiones de fondo en «Hacia la plena vigencia de los Acuerdos del Estado español con la Santa Sede», en Anuario de Derecho Eclesiástico, vol. VII, 1991, p. 197.

87 NAVARRO VALLS, R., El matrimonio religioso..., cit., 1984, pp. 169-177; del mismo Curso de Derecho matrimonial canónico y concordatario, $3^{\mathrm{a}}$ ed., Tecnos, Madrid, 1989, pp. 359 y ss. 
3) no contradicción con ninguno de los elementos integrantes del orden público en una sociedad democrática ${ }^{88} ; \mathrm{y}$

4) conformidad de la causa de nulidad o disolución canónica con las correspondientes causas civiles $^{89}$, ya que, por un lado, la expresión utilizada por el AAJ es «ajuste con el Derecho del Estado» y no simplemente «no contradicción» con ese Derecho y, en todo caso, de otro, la no contradicción o conformidad se refiere al Derecho del Estado (también de los tratados internacionales sobre Derechos Humanos ratificados por España), tanto sustantivo como procesal ${ }^{90}$, ya que la expresión del Acuerdo no distingue entre uno y otro. Ésa es la única manera de evitar que la solución dada por el juez canónico entre en contradicción con la que hubiera dictado el juez civil con arreglo a su Derecho, resultando que el mismo Ordenamiento, el ordenamiento estatal, da soluciones contradictorias al mismo supuesto de hecho, dependiendo todo de que se acuda a uno u otro tribunal, y dejando abiertas las puertas, tanto al fraude de ley si hay acuerdo entre las partes al no estar abierta la posibilidad del recurso del fiscal en defensa de la legalidad, como a la desigualdad entre los ciudadanos.

5) El respeto del derecho de libertad de conciencia de ambos contrayentes, exige el acuerdo y el consentimiento de ambos miembros del matrimonio en que la sentencia de nulidad o la resolución de disolución tengan efectos civiles. Otra cosa implicaría imponer como obligatoria la sumisión a decisiones de Tribunales a los que no se han trasferido competencias constitucionales de acuerdo con el art. $93 \mathrm{CE}$, que además son decisiones confesionales con violación del derecho de libertad religiosa del que se opone a su homologación civil. La homologación tiene su límite en este derecho que no puede violar.

No basta con que el juez civil examine la sentencia canónica desde un punto de vista puramente formal (dos primeros requisitos), sino que es necesario que entre en el examen de fondo de la sentencia (dos últimos requisitos).

88 REINA, V., y MARTINELL, J. M., Curso de Derecho matrimonial, Marcial Pons, Madrid, 1995, pp. 191-200; DELGADO DEL RÍO, G., El matrimonio en forma religiosa, cit., pp. 189 y ss.; MARTINELL, J. M., Procesos matrimoniales civiles. Disfunciones y reformas, PPU, Barcelona, 1990, pp. 280-308; SOUTO, J. A., Derecho eclesiástico del Estado, $3^{\text {a }}$ ed., Marcial Pons, Madrid, 1995, p. 431.

89 LLAMAZARES FERNÁNDEZ, D., El sistema matrimonial español..., cit., pp. 271-281. También se ha mostrado partidario de esta tesis, entre los eclesiasticistas, SUÁREZ PERTIERRA, G., «Matrimonio religioso y divorcio en el Derecho español», en Revista de Derecho Privado, noviembre 1981, espec. pp. 999 y ss. PÉREZ ÁLVAREZ. S., Las sentencias matrimoniales de los tribunales eclesiásticos en el Derecho español. La cláusula de ajuste al orden público constitucional, Tirant lo Blanch, Valencia, 2006. El TEDH ha considerado que la homologación de una sentencia canónica en la que no se ha respetado debidamente el derecho a la defensa y a un juicio contradictorio en el proceso canónico, por habérsele negado a una de las partes información que hubiera necesitado para su defensa y, como consecuencia de ello, no haber sido representada por un abogado, ha violado el art. 6.1 de la CEDH. Ver Pellegrini c. Italia, de 20 de julio de 2001, En Derecho, núms. 33-48. 
Si se han observado los requisitos procesales, el juez civil dará por buena la instrucción del proceso y, por tanto, los hechos probados en el proceso canónico, pero se reserva la calificación jurídica de esos hechos con arreglo al Derecho civil: deberá homologar la sentencia canónica sólo si con arreglo al Derecho civil, él hubiera dado el mismo resultado ${ }^{91}$.

Aparte de que ésta es la única solución que está de acuerdo con las expresiones literales del Acuerdo, que habla de ajuste al Derecho del Estado, es la única congruente con la distinta naturaleza de ambos Derechos, canónico y estatal, confesional el primero y no confesional el segundo, con la consiguiente diferencia esencial entre sus correspondientes tipos matrimoniales, sacramental el primero y no sacramental el segundo ${ }^{92}$.

Los requisitos de validez del matrimonio canónico tienen su razón de ser en asegurar la validez del sacramento: su causa ejemplar es la unión de Cristo con su Iglesia y su causa jurídica $^{93}$ el amor mutuo entre los miembros de la pareja, sin reservas, exclusivo, para siempre e incondicionado, y el fundamento de su capacidad de obligar es la fe.

El juez civil sólo puede homologar directamente las sentencias canónicas que declaren la nulidad por defectos de forma, ya que el art. 60 del CC hace una expresa remisión material a ellas, asumiéndolas como normas civiles ${ }^{94}$. En los demás casos (existencia de impedimentos, o inexistencia o defecto de capacidad o consentimiento), deberá entrar en el examen del fondo de la causa para ver si la aplicación del Derecho civil al caso conduce al mismo resultado. Otra cosa implicaría su actuación como brazo secular de la Iglesia, atribuyendo efectos jurídicos civiles a normas confesionales en cuanto tales, con flagrante violación del principio de laicidad.

Ésta es la única solución enteramente congruente, al mismo tiempo, con el principio de libertad de conciencia, y los de laicidad e igualdad:

$1^{\circ}$ ) Tiene en cuenta que los creyentes se sienten obligados a acudir a los tribunales canónicos por creer que sólo ellos son competentes para decidir sobre la nulidad o disolución de su matrimonio canónico, al que el Derecho del Estado atribuye efectos civiles, como proyección razonable, no obligada, del principio de

91 MARTINELL, J. M., «Matrimonio y libertad de conciencia», en Laicidad y Libertades, núm. 0, pp. 99 y ss. Propone como alternativa de iure condendo el matrimonio civil obligatorio, por considerar inútil el sistema de homologación así concebido.

92 Sobre la diferencia de ambos tipos negociales y de los principios informadores de los mismos cfr. LLAMAZARES FERNÁNDEZ, D., El sistema matrimonial español..., cit., pp. 27-55; también CALVO ESPIGA, A., «Sobre la sacramentalidad del matrimonio de los bautizados. En torno a la relación entre institución matrimonial y sacramento del matrimonio», en Scriptorium Victoriense, vol. 29, 1982, pp. 301-355 y vol. 30, 1983, pp. 129-149.

93 SERRANO POSTIGO, C., La causa típica en el Derecho canónico matrimonial, León, 1980, especialmente, pp. 153 y ss.

94 LLAMAZARES FERNÁNDEZ, D., El sistema matrimonial español..., cit., p. 197. 
cooperación, evitándoles tanto el doble proceso (canónico y civil), contrario al principio de economía procesal y al de igualdad de los ciudadanos, como cualquier posibilidad de colisión entre norma de conciencia y norma jurídica estatal. Al mismo tiempo, sortea el más mínimo atisbo de colisión con los principios de igualdad y laicidad que son, en todo caso, límite de la cooperación, siempre que sea querida por ambas partes. No hay ninguna razón para extender más allá los efectos de ésta, ya que su única razón de ser está suficientemente cumplida. Se trata de una cooperación no obligada, sino que queda a merced de la discrecionalidad de los poderes públicos.

$2^{\circ}$ ) Es la solución que mejor respeta los principios de unidad jurisdiccional (art. 117 $\mathrm{CE}$ ), derecho la tutela efectiva de los Jueces y Tribunales y al juez ordinario predeterminado por la Ley (art. 24.1 y 2 CE) y la consecuente plenitud de las propias competencias jurisdiccionales del juez civil.

$3^{\circ}$ ) Es la solución más congruente con el modelo anglosajón de matrimonio de clase única con pluralidad de formas, en que el matrimonio confesional es mero presupuesto del civil.

$4^{\circ}$ ) Como ya he escrito en varias ocasiones ${ }^{95}$ no vale objetar que según esta solución no serían civilmente homologables las resoluciones pontificias de disolución del matrimonio rato y no consumado, ya que civilmente no existe la inconsumación como causa de disolución, ya que las causas de divorcio son otras. Insisto una vez más: la causa de disolución canónica no es la inconsumación, sino factores que son causa del fracaso matrimonial sin previsión de superación de futuro. Lo que ocurre es que sólo operan como causas de disolución en relación con los matrimonios inconsumados, no con respecto a cualquier matrimonio $y$, evidentemente, se da una clara coincidencia con las causas de divorcio civil que todas ellas pueden reconducirse a esa categoría general: fracaso de hecho del matrimonio sin esperanzas de su posible recomposición futura.

De todas maneras, hay que decir que el sistema que hemos diseñado hasta la entrada en vigor de la nueva Ley de Enjuiciamiento Civil tenía una falla clamorosa ${ }^{96}$. Estaba prevista la posible revisión de la decisión del juez civil, tanto si una de las partes se opone a ella como si es denegatoria de la homologación. Pero no estaba prevista posibilidad alguna de control (a instancias del fiscal y en defensa de la propia ley) de la decisión positiva del juez cuando las dos partes están de acuerdo, teniendo efectos de cosa juzgada, tanto en sentido material como formal ${ }^{97}$. De ahí se deducen dos consecuencias: $1^{\text {a }}$ ) que era posible que se homologaran sentencias canónicas no homologables ni siquiera con arreglo a la tesis de la suficiencia de no contradicción con el orden público (nulidades con base en impedimentos de naturaleza confesional), lo que no dejaba de ser una seria anomalía; $2^{\text {a }}$ ) que, en última instancia, se dejara en manos de la voluntad de las partes la decisión tanto de declaración de nulidad como de disolución de su matrimonio, con lo que se reforzaba el principio consensualista en el Derecho civil, pero sólo para los católicos, poniendo en entredicho a la igualdad.

95

96

97

LLAMAZARES FERNÁNDEZ, D Ibidem, pp. 278-281.

LLAMAZARES FERNÁNDEZ, D., ibidem, pp. 286-290.

MARTINELL, J. M., Procesos matrimoniales civiles..., cit., p. 305. 
La nueva LEC, al derogar las disposiciones adicionales de la Ley 30/1981, de 7 de julio, relativas al matrimonio y en las que se establecía el procedimiento a seguir en las causas de nulidad, separación y divorcio, abre la posibilidad de recurrir el auto de homologación también en el supuesto de que sea afirmativa y no haya oposición de ninguna de las partes (art. 778 en relación con el 770 y con los arts. 455 y 468).

Nuestro Tribunal Supremo ha ido acercando paulatinamente su criterio a la orientación que venimos defendiendo.

En una primera sentencia de 1994 el Tribunal ${ }^{98}$ estima que «la eficacia en el orden civil de las sentencias canónicas depende exclusivamente, sin mayores cortapisas, de la superación de un juicio de homologación que se ciñe a dos extremos concretos: a) autenticidad de la sentencia firme... y b) adecuación de la sentencia (en su contenido), al Derecho del Estado, lo cual comporta un examen a fondo que sólo se extiende a constatar si las declaraciones de la sentencia, no están en contradicción con los conceptos jurídicos y disposiciones equiparables o análogas del Derecho estatal de manera que no se vea perjudicado o alterado el sistema de libertades públicas y derechos fundamentales del ciudadano español».

La expresión «conceptos jurídicos y disposiciones equiparables o análogas del derecho del Estado» sólo puede entenderse referida a los principios constitucionales, a los conceptos jurídicos, principios y normas de la regulación civil del matrimonio. Añádase a todo ello que en este caso no contradicción viene a coincidir, desde el punto de vista de los resultados, con lo que otros hemos llamado «conformidad».

En cambio, en otra sentencia de un año más tarde ${ }^{99}$, se decantaba formalmente por el criterio de que bastaba con que la sentencia canónica no contradijera al orden público del Estado, aunque entendido éste en un sentido muy amplio, de dudosa constitucionalidad, flexible y variable «al conformarse por principios no sólo jurídicos públicos y privados, sino también por políticos, económicos, morales e incluso religiosos y hasta supranacionales, que hay que preservar para el mantenimiento de la paz y orden social en toda su amplitud, y a su vez en atención a su relatividad por causa de la concepción social-política de cada momento histórico» ${ }^{100}$.

De otra parte, con toda razón, negaba que la competencia del juez civil para entrar en el examen del fondo de la causa se pudiera extender a examinar la corrección de la aplicación de las normas canónicas por la autoridad eclesiástica en su propio ámbito $^{101}$ y a rechazar la pretensión del recurrente de que se declarara nula la sentencia recurrida utilizando como argumento que la causa de disolución canónica, no consumación del matrimonio, no existía en el Código civil. Pero no porque el Tribunal no esté de acuerdo con esa afirmación, sino porque de aceptar tal argumento se llegaría a la conclusión de que quedaría sin aplicación una de las

\footnotetext{
98 STS de 1 de julio de 1994, FJ 3.

$99 \quad$ STS de 23 de noviembre de 1995.

100 Ibidem, FJ 1, párr. 8 y párr. 14.

101 Ibidem, párrs. 11-12.
} 
cláusulas del art. VI del AAJ de 1979 con la Iglesia católica ${ }^{102}$. Es decir, sobre la base de algo falso que revela un desconocimiento notable del Derecho Canónico, ya que la inconsumación no es causa sino sólo presupuesto de la disolución. Los cánones 1142, 1698 y 1704, distinguen perfectamente entre inconsumación y causa justa cuya existencia real condiciona la validez misma de la decisión pontificia. Pues bien, la mayor parte de las causas estimadas justas por la Santa Sede son perfectamente subsumibles en alguna de las causas civiles de divorcio.

Sobre la base de la identificación entre inconsumación y justa causa de la disolución el Tribunal rechazaba expresamente la tesis de la necesidad de identidad entre causas de disolución o nulidad canónicas y civiles.

En contra de lo que algunos autores han estimado, el TS no ratifica estos criterios en ninguna otra sentencia posterior, salvo en algún obiter dictum, que no crea jurisprudencia.

Sí ha emitido, en cambio, tres sentencias con distintos criterios que muestran una evolución en el sentido que hemos indicado.

Dos de ellas son casi simultáneas ${ }^{103}$.

En la primera, lo que se exige de la sentencia canónica para que sea homologable civilmente es que no esté en contradicción, no con el orden público sin más, sino «con los conceptos jurídicos y disposiciones equiparables o análogas del Derecho estatal» ${ }^{104}$, es decir, las normas del Código civil sobre el matrimonio. Reproduce literalmente las expresiones de la primera sentencia pronunciada sobre el tema.

Tampoco la segunda alude al orden público como referencia de la no contradicción; lo que se exige para la homologación civil de la sentencia canónica es que no se oponga a «los principios constitucionales y los principios rectores del matrimonio, de acuerdo con los principios jurídicos de nuestro ordenamiento» ${ }^{105}$. Ni que decir tiene que entre esos principios constitucionales y principios rectores del matrimonio civil hay que encuadrar al principio de laicidad. Añade además algo que debilita el rechazo de la tesis de identidad de causas o más correctamente de que las causas canónicas sean subsumibles en alguna civil: que no es exigible la coincidencia absoluta porque «si la similitud es posible y bastante no tiene por qué producirse» la coincidencia «absoluta»; la diversidad es perfectamente explicable «a causa de la diversidad de los correspondientes ordenamientos en relación» (civil y canónico) pero, sin convertirlos en «contradictorios» ${ }^{106}$.

Entendemos que ésta es la doctrina jurisprudencial consolidada y reiterada en el sentido del artículo 3 de nuestro Código civil.

\footnotetext{
102 Ibidem, párr. 13.

103 SSTS de 5 y 8 de marzo de 2001.

104 FJ 3, b).

105 FJ 3, párr. 4.

106 FJ 3, párr. 5.
} 
Lo criticable del fallo de estas dos sentencias es consecuencia del incorrecto conocimiento de la diversidad entre consentimiento matrimonial canónico y consentimiento matrimonial civil, que no son equiparables y que en no pocos aspectos son contradictorios. Las mismas expresiones aluden a conceptos y realidades distintas que, de no ser tenidas en cuenta, conducen inexorablemente a la contradicción interna del ordenamiento civil.

La misma doctrina jurisprudencial se mantiene en una sentencia posterior de $2005^{107}$, pero con el añadido de que se trata de un matrimonio canónico civilmente disuelto en virtud de sentencia de divorcio cuyos efectos no quedan afectados por la sentencia posterior canónica de nulidad.

Entendemos que cualquier otra solución es incompatible con el sistema de matrimonio civil único con libertad en cuanto a su forma de celebración. A ese diseño responden inequívocamente y sin ambigüedad alguna los artículos 73, 81 y 85 del Código civil. No tiene sentido admitir la posibilidad de que el mismo juez civil en relación con un mismo matrimonio deba pronunciarse negativamente si aplica el derecho civil y negativamente si ejecuta la correspondiente resolución canónica.

No debe olvidarse que las normas matrimoniales civiles constituyen ius cogens y que dejarlas sin eficacia para unos ciudadanos sobre la base de una decisión personal suya implica una violación de la igualdad; tanto más grave si tenemos en cuenta que la razón de la discriminación, son las creencias religiosas.

En la tercera ${ }^{108}$ se aportan dos ideas importantes:

$1^{\text {a) }}$ la sentencia obtenida en proceso canónico de nulidad matrimonial realizado en ausencia de una de las partes no es civilmente homologable por aplicación del art. 24.1 CE, si la no comparecencia no fue voluntaria y directamente querida $\mathrm{y}$, si fue voluntaria y querida no sólo por aplicación del principio de libertad religiosa, sino «sobre todo» por imperativo del principio de aconfesionalidad (laicidad) ${ }^{109}$, que es principio básico incuestionable para la sentencia, en la que se identifican, a efectos prácticos, aconfesionalidad y libertad religiosa plena o absoluta ${ }^{110}$.

107 STS de 23 de marzo de 2005, FJ 1.

108 STS de 17 de junio de 2002.

109 Ibidem, FJ 1, párr. 7: «Ya que en el primer caso -no voluntariedad- le debe amparar el principio de tutela judicial efectiva del artículo 24 de la Constitución Española; y en el segundo -voluntariedad- le ampara el principio, que ya se dijo que iba a ser la tesis rectora en el estudio de este motivo, la de la libertad religiosa establecida en el artículo 16 de dicho Texto, y sobre todo el de la aconfesionalidad del Estado». Ver RODRÍGUEZ CHACÓN, R., «Ineficacia civil de sentencia canónica dictada en rebeldía. ¿̇nicio de una innovadora línea jurisprudencial?», en El Derecho, pp. 1-4.

110 STS de 17 de junio de 2002, FJ 1, párr. 1. 
La sentencia de nulidad obtenida en rebeldía de una de las partes no es civilmente homologable no sólo en el caso de que se trate de rebeldía a la fuerza, sino también en los casos de rebeldía por convicción e, incluso, de rebeldía por interés ${ }^{111}$.

Consecuencia obligada sería también la aplicación de esta doctrina, puesto que existe la misma razón, a los supuestos de oposición de una de las partes a la homologación civil de una resolución canónica e, incluso, a la exigencia, como requisito para esa homologación, del consentimiento expreso de ambas partes. Pondría en cuestión la doctrina constitucional anterior que exigía, recordémoslo, incluso en el caso de la oposición de una de las partes, que esa oposición fuera razonada.

Una sentencia posterior del mismo Tribunal ${ }^{112}$, habida cuenta de algunos reglamentos europeos y de su incidencia hermenéutica en el Derecho interno español, restringe la rebeldía únicamente a la rebeldía involuntaria, excluida en todo caso la rebeldía voluntaria por interés, y admite la rebeldía voluntaria, como una especie de objeción de conciencia, ponderadas las circunstancias y los derechos en juego en cada caso particular.

"Para apreciar que la libertad ideológica y religiosa justifica el incumplimiento de la carga de comparecer ante los tribunales eclesiásticos y, con ello, impide reconocer efectos civiles a la resolución dictada, como excepción a lo que establecen las normas de rango legal aplicables en el Derecho interno, es menester valorar las circunstancias que concurren en cada caso para examinar si se ha alegado de manera razonable la existencia de unas convicciones de la persona que hagan incompatible la comparecencia ante el tribunal eclesiástico con su libertad ideológica o religiosa, y valorar su trascendencia teniendo en cuenta la afectación concreta del derecho, los efectos negativos que conlleva la omisión de la carga de comparecer y la ponderación de estas circunstancias frente a los restantes valores y derechos constitucionales que puedan estar en juego (dado que los límites de la libertad religiosa radican en la protección del derecho de los demás al ejercicio de sus libertades públicas y derechos fundamentales, así como la salvaguardia de la seguridad, de la salud y de la moralidad públicas: art. 16.1 CE y 3.1 LOLR, o en "los que le imponen el respeto a los derechos fundamentales ajenos y otros bienes jurídicos protegidos constitucionalmente”: SSTC 141/2000, de 29 de mayo, FJ 4; 154/2002, de 18 de julio, FJ 7 y 296/2005, FJ 4), entre los que figura el derecho a la tutela judicial efectiva inherente al reconocimiento de la eficacia de sentencias eclesiásticas si se reconoce por el Ordenamiento interno (STC 66/1982, de 10 de diciembre), teniendo en cuenta, entre otras circunstancias, que la persona que ha

111 Ver comentario crítico a la sentencia en, CAÑAMARES, S., «La rebeldía en el proceso canónico y su proyección sobre el reconocimiento de efectos a las sentencias eclesiásticas. Consideraciones acerca de la Sentencia 644/2002 del Tribunal Supremo de 27 de junio», separata; RODRÍGUEZ CHACÓN, R,., «Ineficacia civil de sentencia canónica dictada en rebeldía. ¿Inicio de una innovadora línea jurisprudencial...?», en El Derecho, núm. 166, 2 de octubre, 2002, pp. 1-4, se manifiesta, en cambio decididamente a favor del nuevo criterio jurisprudencial; AMÉRIGO CUERVO-ARANGO, F., «Crónica jurisprudencial: España», en Laicidad y Libertades, núm. 2, pp. 602-604.

112 STS de 24 de octubre de 2007, FJ 3, D. 
contraído matrimonio canónico parece haber aceptado, en principio, los postulados confesionales que esta forma de contraer matrimonio supone, entre los cuales figura la jurisdicción de los tribunales eclesiásticos, cuyos efectos civiles son reconocidos con determinados límites por el Estado, para decidir acerca de la nulidad y de la separación, circunstancia que, obviamente, no excluye la posibilidad de una mutación de dichas convicciones en la persona afectada que pueda ser relevante para justificar su incomparecencia ante dichos tribunales.

Resulta, así, que la doctrina fijada en la sentencia que acabamos de referirnos no puede tener, con arreglo al contexto normativo que procede tomar en consideración, una aplicación abstracta, sino que su aplicación debe quedar reservada a los supuestos en que el juicio de ponderación tras la alegación de las convicciones religiosas o ideológicas que se estiman relevantes para justificar la incomparecencia concluya en la existencia de una afectación del derecho a la libertad ideológica o religiosa no justificada por la prevalencia de otros derechos o intereses protegidos por la Constitución”.

$2^{\mathrm{a}}$ ) La conformidad exigible entre ordenamiento canónico y ordenamiento civil (cláusula de ajuste) no es de nombres sino de contenido. En el derecho canónico no se habla de rebeldía sino de ausencia: los términos son diferentes pero el contenido semántico es el mismo ${ }^{113}$. Y lo mismo debe valer a la inversa; no basta que haya coincidencia de términos sino de contenidos semánticos. No se puede traducir consentimiento matrimonial canónico por consentimiento matrimonial civil como ha hecho el TS en una de las sentencias anteriormente citadas: el contenido de derechos y obligaciones de uno y otro consentimiento son muy diferentes y la falta de alguno de ellos acarrea consecuencias muy distintas en uno y otro Derecho. Decir que en las causas matrimoniales de incapacidad para asumir las obligaciones matrimoniales lo que hay es falta de consentimiento matrimonial para a renglón seguido, como si fuera la menor de un silogismo, afirmar que también en el Código civil es nulo el matrimonio sin consentimiento matrimonial ${ }^{114}$, es un argumento radicalmente viciado y, por tanto, falso.

La modificación de los artículos del CC referidos a la separación y al divorcio obliga a plantearse la discusión en otros términos. Dado que es posible el divorcio civil no sólo por consenso de ambas partes sino por voluntad de una de ellas aunque la otra se oponga, no parece haber dificultad alguna para homologar los supuestos de disolución canónica de matrimonio rato y no consumado. Por lo que respecta a la homologación civil de las causas de nulidad canónica, en cambio, las cosas no varían sustancialmente, ya que el CC sigue manteniendo también la categoría de nulidad con efectos distintos del divorcio, fundamentalmente la retroactividad o no retroactividad y la del derecho a pensión de cualquiera de los cónyuges en caso de divorcio (art. 97) o sólo a indemnización el cónyuge de buena fe en caso de declaración de nulidad (art. 98). Lo razonable sería que desaparecieran tales

113 FFJJ 5 y 6.

114 STS de 8 de marzo de 2001, FJ 3; del mismo, «Libertad de conciencia y matrimonio», en Laicidad y Libertades, cit., pp. 80-81; también RODRÍGUEZ GARCÍA, J. A., «El derecho a celebrar ritos matrimoniales», en Laicidad y Libertades, núm. 0, pp. 107-134. 
diferencias. No se entiende la razón por la que el legislador las mantiene. De iure condendo, la discusi8ón doctrinal anterior, no tendría ya sentido.

\section{MATRIMONIO CIVIL Y RITOS MATRIMONIALES ÉTNICOS}

El profesor MARTINELL ${ }^{115}$ ha apuntado un vacío, acaso no suficientemente justificado, en esta descripción del sistema matrimonial, en la que se guarda silencio a propósito de la posible atribución de efectos civiles a los matrimonios celebrados con arreglo a la forma y ritos de una determinada etnia (el matrimonio gitano p.e.). La denuncia es certera, pero nuestro CC vigente no deja abierta tal posibilidad, ya que los arts. 49 y 59 CC se refieren expresamente sólo a la forma religiosa. Habría que pensar en la oportunidad de esa solución, en cuanto esas formas rituales no entren en colisión con principios constitucionales, en el marco de la autonomía que se reconociera a las minorías, a imagen de las Confesiones religiosas, como tendremos ocasión de ver más adelante. En una reciente sentencia el TC, a la par que niega el derecho a pensión, da por supuesta la posibilidad de que el legislador abra esa posibilidad y reconozca como matrimonio civil esa unión. "Cuestión distinta es que los poderes públicos, en cumplimiento del mandato del art. 9.2 CE, puedan adoptar medidas de trato diferenciado de ciertos colectivos en aras de la consecución de fines constitucionalmente legítimos, promoviendo las condiciones que posibiliten que la igualdad de los miembros que se integran en dichos colectivos sean reales y efectivas o removiendo los obstáculos que impidan o dificulten su plenitud. En este sentido pudieran tomarse en consideración las peculiaridades y el carácter de minoría étnica de la comunidad gitana, en línea con los principios del Convenio Internacional sobre la Eliminación de todas las Formas de Discriminación Racial de 21 de diciembre de 1965 (BOE de 17 de mayo de 1969), y con las previsiones de su art. 1.4. Ahora bien, en defecto de dicha regulación, no cabe pretender un trato desigual, bajo la invocación del art. 14 CE». «Por tanto, sin perjuicio de que el legislador pudiera, en atención a las singularidades que plantea la etnia gitana, desarrollar una regulación legal en la que, preservando los derechos y valores constitucionales, se establecieran las condiciones materiales y formales en que las uniones celebradas conforme a los ritos y usos gitanos pudieran contar con plenos efectos civiles matrimoniales, verificado que no ha existido un trato discriminatorio ni por motivos sociales ni por razones étnicas o raciales, el presente recurso de amparo debe ser denegado».

Llevado el caso ante el TEDH este se ha pronunciado en el sentido siguiente ${ }^{116}$ : 1) ha re conocido el derecho a pensión de viudedad habida cuenta de que en el momento de e contraer matrimonio por el rito gitano, no había posibilidad en España otro matrimonio que el canónico, salvo que se demostrara la no pertenencia a la Iglesia católica; de que la administración se había tomado decisiones que implicaban el reconocimiento de estatus matrimonial; a todo lo cual había que añadir la buena fe de la viuda; 2) que el matrimonio gitano carece de validez en España y que no puede prosperar el recurso de que esto implique trato discriminatorio de la minoría gitana,

115 «Derecho a celebrar ritos matrimoniales...», cit., pp. 668-671.

116 STEDH de 8 de diciembre de 2009 Muñoz Díaz v. España. 
ya que el matrimonio de otras minorías (judíos, protestantes y musulmanes) a los que se reconoce eficacia civil se hace sobre la base de lo estipulado en el correspondiente acuerdo.

Pero el código civil abre también la puerta a la decisión unilateral del estado, con total respeto del principio de seguridad jurídica, claro está. La pregunta es si la renuncia ese ejercicio unilateral, reservando esa posibilidad a las confesiones con acuerdo de cooperación, no estará teniendo consecuencias perjudiciales, no debidamente justificadas, para quienes no son beneficiarios de los acuerdos.

De otro lado, es verdad que nuestro Código civil sólo confiere efectos civiles a los matrimonios celebrados en forma religiosa, siempre que se trate de confesiones inscritas, bien de conformidad con lo acordado o con lo dispuesto con carácter general por la ley civil. La pregunta es si no habría que tener en cuenta también a los ritos matrimoniales de las minorías aunque no sean religiosos, porque otra cosa implicaría discriminación no debidamente justificada de la minoría, si tenemos en cuenta que también las minorías son asociaciones de convicción que están bajo el amparo del art. 16 CE como las confesiones religiosas o las asociaciones filosóficas. 